HINDENBURGO ELVAS GONÇALVES DE SÁ

UM MÉTODO BASEADO EM INTELIGÊNCIA COMPUTACIONAL PARA A GERAÇÃO AUTOMÁTICA DE CASOS DE TESTE DE CAIXA PRETA

São Paulo

2010 
HINDENBURGO ELVAS GONÇALVES DE SÁ

\title{
UM MÉTODO BASEADO EM INTELIGÊNCIA COMPUTACIONAL PARA A GERAÇÃO AUTOMÁTICA DE CASOS DE TESTE DE CAIXA PRETA
}

\author{
Dissertação apresentada à Escola \\ Politécnica da Universidade de São Paulo \\ para a obtenção do título de Mestre em \\ Engenharia.
}

São Paulo

2010 
HINDENBURGO ELVAS GONÇALVES DE SÁ

\section{UM MÉTODO BASEADO EM INTELIGÊNCIA COMPUTACIONAL PARA A GERAÇÃO AUTOMÁTICA DE CASOS DE TESTE DE CAIXA PRETA}

Dissertação apresentada à Escola

Politécnica da Universidade de São Paulo para a obtenção do título de Mestre em Engenharia.

Área de Concentração: Sistemas Digitais

Orientador: Prof. Dr. Edison Spina

São Paulo

2010 
Este exemplar foi revisado e alterado em relação à versão original, sob responsabilidade única do autor e com anuência de seu orientador.

São Paulo, 08 de Outubro de 2010.

Assinatura do autor:

Assinatura do orientador:

FICHA CATALOGRÁFICA

Sá, Hindenburgo Elvas Gonçalves de

Um método baseado em inteligência computacional para geração automática de casos de testes de caixa preta / H.E.G. de Sá. ed. rev. São Paulo, 2010.

p. 83

Dissertação (Mestrado) - Escola Politécnica da Universidade de São Paulo. Departamento de Engenharia de Computação e Sistemas Digitais.

1. Engenharia de software (Análise; Testes) 2. Fuzzy (Inteli gência artificial) 3. Aprendizado computacional I. Universidade de São Paulo. Escola Politécnica. Departamento de Engenharia de Computação e Sistemas Digitais II. t. 


\section{DEDICATÓRIA}

Dedico este trabalho aos meus pais pelo grande apoio, amor e ensinamentos. 


\section{AGRADECIMENTOS}

Ao Grande Arquiteto do Universo, Deus, por me proporcionar uma oportunidade única e me confortar em todos os momentos da vida.

À Rosilene, meu grande amor, pela admiração, compreensão, amizade, importante e incansável apoio ao longo do período de elaboração deste trabalho.

Aos meus dois grandes heróis, Gabriel e Benício, meus filhos e amigos.

Aos meus irmãos Rosângela e Rommel, pelo apoio e confiança.

A Coordenação de Aperfeiçoamento de Pessoal de Nível Superior - CAPES Pela criação e regulamentação do Minter

Ao Prof. Dr. Edison Spina, meu orientador, pela atenção, amizade e grande apoio durante o processo de definição, orientação e confiança depositada neste trabalho.

A Superintendência da Zona Franca de Manaus - SUFRAMA pelo patrocínio financeiro do MINTER.

À Universidade Estadual do Amazonas - UEA, Por gerar as condições e propiciar o oferecimento do programa de Pós-Graduação da EPUSP em Manaus.

À Fundação de Amparo à Pesquisa do Estado do Amazonas, pela concessão da bolsa de mestrado para o cumprimento do estágio obrigatório.

Ao Coordenador do Curso de Pós-graduação em Engenharia Elétrica da Escola Politécnica, Prof. Dr. Marco Túlio Cavalcante de Andrade, por colocar à disposição o laboratório Knoma.

Ao Instituto Certi Amazônia pelo apoio e colaboração. 
"Cavalheiros, o que pode ser mais fácil que colocar esse ovo em pé, algo que vocês disseram ser impossível? É a coisa mais simples do mundo. Qualquer um poderia fazer - depois de saber como."

Cristóvão Colombo 


\section{RESUMO}

Este trabalho de dissertação apresenta um método baseado em técnicas de inteligência computacional, como aprendizado de conjunto de regras, redes neurais artificiais e lógica fuzzy, para propor o desenvolvimento de ferramentas capazes de gerar e classificar casos de testes de caixa preta com as finalidades de auxiliar na atividade de preparação de testes, na detecção de defeitos em características ou funcionalidades e na diminuição do tempo de detecção de correção do software visando, com isto, atingir uma cobertura de testes qualitativamente superior ao processo criação manual. A obtenção de novos casos de testes e a classificação dos casos de testes gerados utilizam técnicas de aprendizado de um conjunto de regras, utilizando algoritmos de cobertura seqüencial, e de uma máquina de inferência fuzzy. A definição dos métodos, tanto para gerar como para classificar os casos de testes, foram fundamentados em experimentos visando comparar as similaridades entre os métodos fuzzy, redes neurais artificiais e aprendizado de conjunto de regras. Por fim, procurou-se desenvolver uma ferramenta à titulo de prova de conceitos objetivando aplicar os métodos que obtiveram melhores resultados nas experimentações. Os critérios adotados para definir os métodos foram às métricas de complexidade ciclomática e total de linhas de código (LOC).

Palavras chaves: engenharia de software (análise; testes). fuzzy (inteligência artificial). aprendizado computacional. 


\section{ABSTRACT}

This dissertation work presents a method based on computational intelligence techniques, such as learning set of rules, artificial neural networks and fuzzy logic, proposed the development of tools that generate test cases and sort of black box with the purposes of assisting activity in the preparation of tests for detection of defects in features or functionality and decreasing the detection time correction software aimed, with this, reach a qualitatively higher test coverage to the manual creation process. The acquisition of new test cases and classification of test cases generated using techniques Learning learning a whole set of Regrasregras using sequential covering algorithms, and a fuzzy inference machine. The definition of methods, both to generate and to classify the test cases were substantiated in experiments aimed at comparing the similarities between the fuzzy methods, neural networks and learning of the rule set. Finally, we sought to develop a tool for evidence of concepts aiming to apply the methods which obtained better results in trials. The criteria adopted to define the methods were metrics cyclomatic complexity and total lines of code (LOC).

Keywords: software engineering (analysis, tests). fuzzy (artificial intelligence). computational learning. 


\section{LISTA DE ILUSTRAÇÕES}

Figura 1 - Classificação de termos para teste de Software.....................................25

Figura 2 - Representação de um cenário típico de atividade de teste.......................26

Figura 3 - Fases da Atividade de Teste de Software.............................................. 31

Figura 4 - Níveis de Maturidade do TMM ...............................................................

Figura 5 - Algoritmo que retorna o tipo de triângulo. ............................................... 41

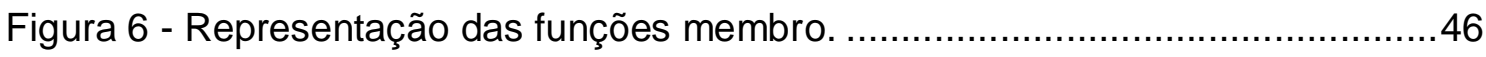

Figura 7 - Representação de um modelo de inferência de Mamdani........................49

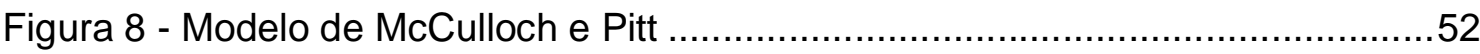

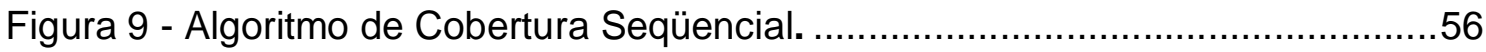

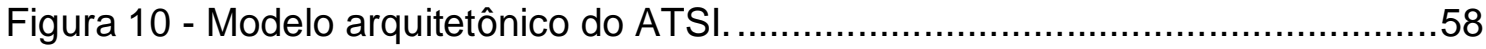

Figura 11 - Representação da Base de Conhecimentos .......................................59

Figura 12 - Representação do Gerador de Casos de Testes ...................................60

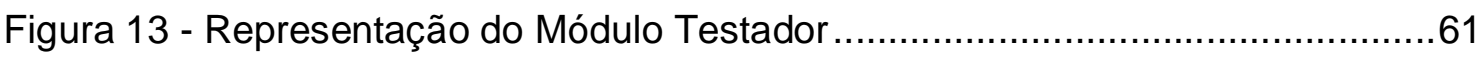

Figura 14 - Representação do Classificador de Casos de Testes.............................62

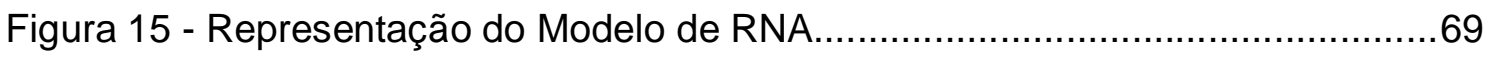

Figura 16 - Code Metrics do MS-Visual Studio 2008............................................

Figura 17 - Algoritmo utilizado para executar o modelo Fuzzy .................................72

Figura 18 - Algoritmo utilizado para executar o modelo RNA ....................................73

Figura 19 - Execução das funções fuzzy e RNAs. ..................................................73 


\section{LISTA DE TABELAS}

Tabela 1 - Termos que representam o conceito de Teste de Software....................22

Tabela 2 - Conceitos de Termos em Teste de Software. .....................................23

Tabela 3 - Atributos de Qualidade...................................................................28

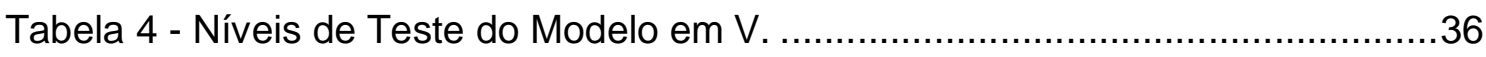

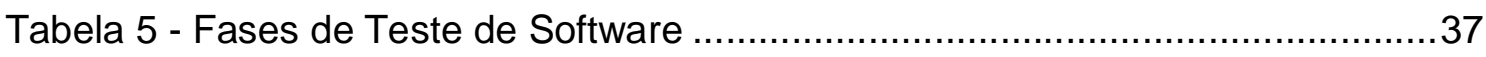

Tabela 6 - Variáveis de entrada e classes válidas e inválidas. ..............................42

Tabela 7 - Condições de existência para cada tipo de triângulo. ..........................42

Tabela 8 - Casos de testes para o critério particionamento de equivalência. ...........42

Tabela 9 - Valores de antecedentes e conseqüentes .....................................48

Tabela 10 - Principais Conceitos relacionados com Aprendizado Supervisionado ...55

Tabela 11 - Modelagem fuzzy para desempenho de computadores......................67

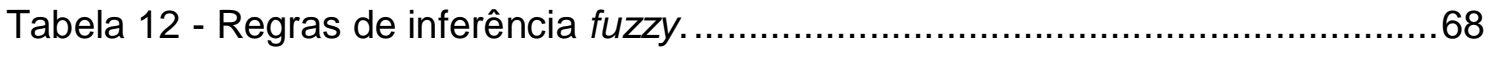

Tabela 13 - Resultados obtidos.......................................................... 74 


\section{LISTA DE GRÁFICOS}

Gráfico 1 - Gráfico comparativo entre LCs Fuzzy x RNAs..................................75 Gráfico 2 - Gráfico comparativo entre a Complexidade Ciclomática Fuzzy e RNAs. 75 Gráfico 3 - Gráfico Comparativo do Tempo de Execução entre Fuzzy e RNAs. .......76 


\section{LISTA DE DIAGRAMAS}

Diagrama 1 - Diagrama de Casos de Uso do ATSI..............................................63 


\section{LISTA DE ABREVIATURAS E SIGLAS}

$\begin{array}{ll}\text { API } & \text { Application Program Interface } \\ \text { ATSI } & \text { Automatic Test Software Interface } \\ \text { CMM } & \text { Capability Maturity Model } \\ \text { GQS } & \text { Garantia da Qualidade de Software } \\ \text { IEC } & \text { International Electrotechnical Commission } \\ \text { IEEE } & \text { Institute of Electrical and Electronics Engineers } \\ \text { IFN } & \text { Info Fuzzy Network } \\ \text { ISO } & \text { International Organization for Standardization } \\ \text { SPICE } & \text { Software Improvement \& Capability Determination } \\ \text { SWEBOK } & \text { Software Engineer Book Of Knowledge } \\ \text { TMM } & \text { Test Maturity Model } \\ \text { UML } & \text { Unified Modeling Language }\end{array}$




\section{SUMÁRIO}

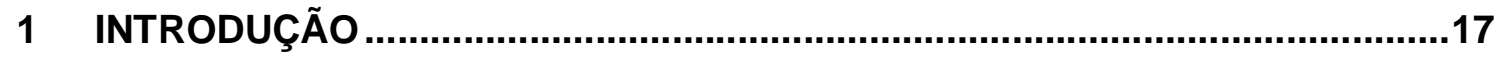

1.1 Objetivos

1.2 Justificativa

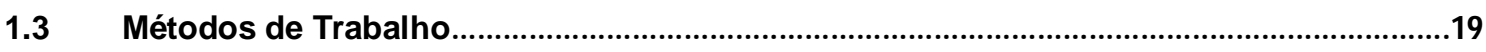

1.4 Organização do Trabalho .....................................................................................20

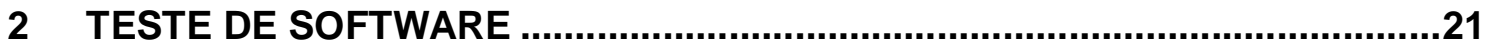

$2.1 \quad$ Conceitos de teste de software

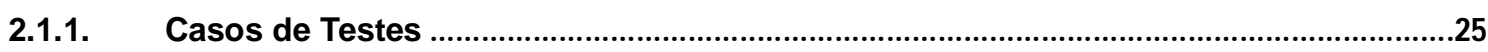

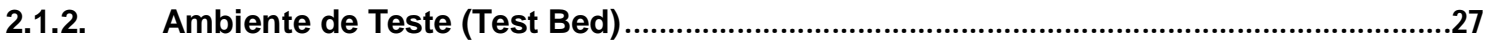

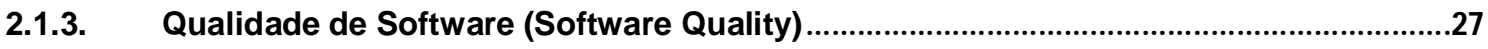

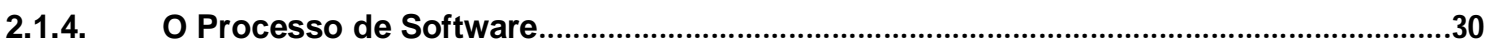

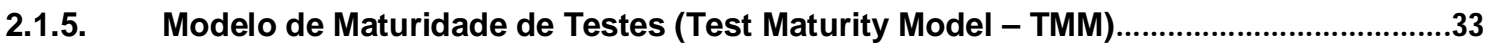

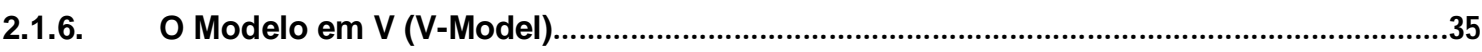

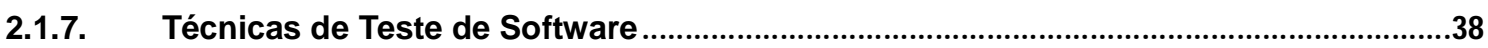

2.2 Testes funcionais

2.3 Considerações Parciais

3 INTELIGÊNCIA COMPUTACIONAL .........................................................44

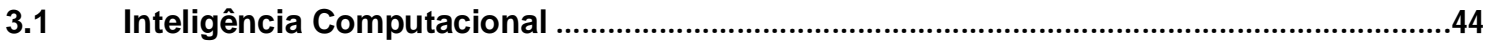

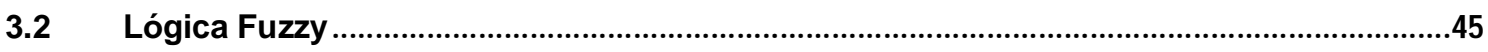

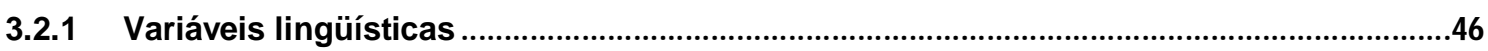

3.2.2 Regras de Produção Fuzzy

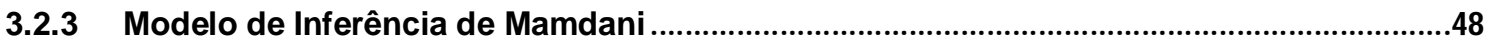

3.2.4 Modelo de Inferência de Takagi-Sugeno-Kano..............................................................51 


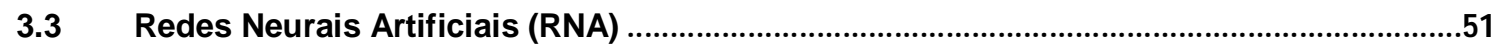

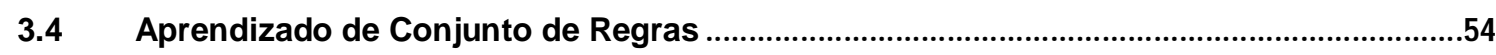

3.5 Considerações Parciais

4 O GERADOR AUTOMÁTICO DE CASOS DE TESTES ................................57

4.1 Modelo conceitual do gerador automático de casos de teste .........................................57

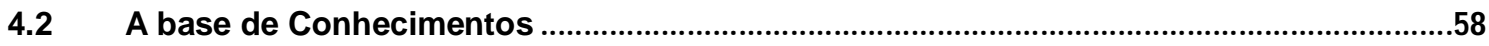

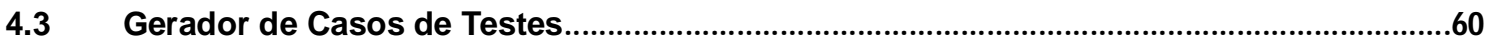

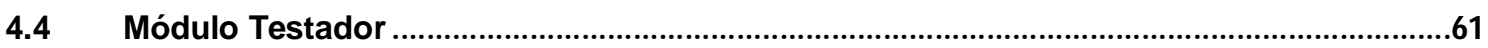

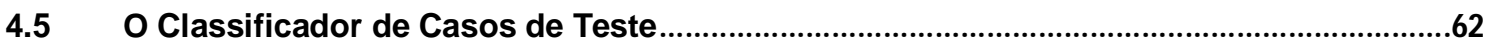

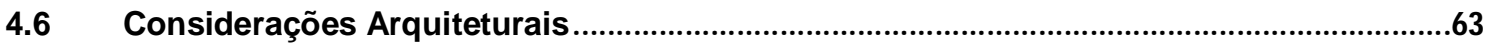

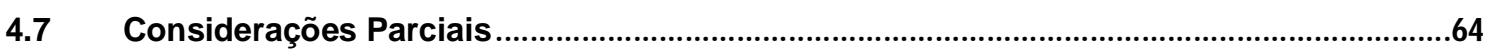

5 PROVA DE CONCEITO............................................................................65

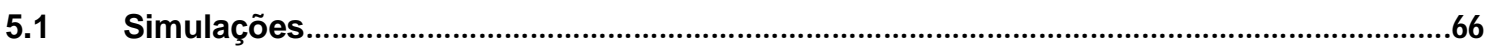

5.2 Análise dos Resultados.........................................................................................

5.3 Considerações Parciais

6 CONSIDERAÇÕES FINAIS .......................................................................77

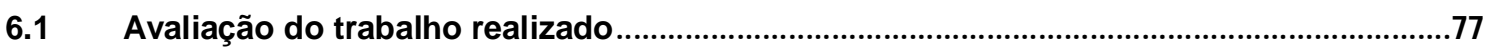

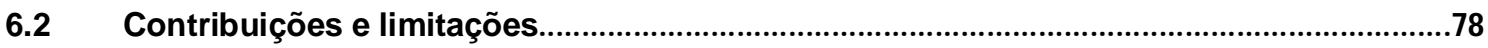

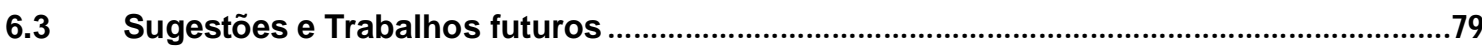

REFERÊNCIAS .............................................................................................80 


\section{INTRODUÇÃO}

Os sistemas de software vêm se tornando cada vez mais presentes e necessários no cotidiano humano. Para garantir que estes sistemas de software correspondam às expectativas de quem os utiliza é importante ressaltar que:

Existem iniciativas para a criação de modelos de avaliação e melhoria do processo de desenvolvimento de software, visando a Garantia da Qualidade de Software (GQS), como: Modelos de Maturidade (Capability Maturity Model - CMM), (Capability Maturity Model Integration - CMMI) e a norma ISO/IEC 15504 (Software Improvement \& Capability Determination - SPICE) (DINIZ, 2008, p. 8)

O processo de desenvolvimento de software tem a responsabilidade da construção do sistema de software e garantir suas funcionalidades conforme as especificações ou requisitos do projeto de software.

Mesmo com o esforço e empenho dos desenvolvedores, ou engenheiros de software, estes sistemas são susceptíveis a falhas ou defeitos. Segundo Charette (2007), "os softwares falham por razões conhecidas e evitáveis, como: má documentação ou inexistência dela; impossibilidade de cumprir os requisitos ou por não estarem claros o suficiente", ou por estarem em constante mudança ou talvez pela ausência de uma pessoa-chave que tenha profundos conhecimentos sobre o processo objeto do sistema de software.

A fase de validação, ou teste, no processo de desenvolvimento de software é importante no sentido de auxiliar a manter o software sobre controle em outras palavras, cumprindo com o que fora especificado nos requisitos. Os testes funcionais, ou de caixa preta, objetivam testar o software mesmo sem o conhecimento de como as instruções internas estão desenvolvidas, baseando-se apenas nos requisitos, ou especificações do software.

O engenheiro de teste elabora um conjunto de casos de testes para simular o uso do software fazendo um confronto entre as entradas fornecidas, os resultados esperados e os resultados obtidos. Este conjunto de casos de testes também é conhecido como massa de teste. Para Bernardo e Kon (2008, p. 54) "muitas empresas possuem certo nível de automação para a formação da massa de testes 
no qual, os casos de testes são armazenados em arquivos texto para posteriormente serem interpretados e executados por um programa".

Gerar dados de teste não pode ser considerado um processo simples: :

Sem automação, o processo torna-se lento, caro e sujeito a erros. No entanto, as técnicas para automatizar a geração de dados de teste devem responder a uma variedade de critérios funcionais e não-funcionais e deve, implícita ou explicitamente, resolver problemas que envolvem a propagação do estado e satisfação de restrições (HARMAN, 2007).

Neste contexto, propõe-se o emprego de técnicas de inteligência computacional visando o desenvolvimento de uma ferramenta que possa, a partir de uma base de exemplo, gerar novos casos de testes como, também, analisar os resultados obtidos com a execução dos testes e classificá-los como um caso de teste "Aderente", o que tem grande chance de encontrar ou que apontou falhas. Um caso de teste é classificado como "Pouco Aderente", quando o resultado obtido for igual ao resultado esperado. Um caso de testes é classificado como "Não Aderente" quando não se aplica ao conjunto de argumentos de entrada do software a ser testado.

\subsection{Objetivos}

Esta pesquisa tem como principal objetivo propor a implementação de uma ferramenta capaz de gerar automaticamente casos de testes funcionais e unitários, baseada em técnicas de inteligência computacional, tais como aprendizado de conjunto de regras e lógica fuzzy, buscando aumentar a eficiência e a eficácia dos resultados produzidos pelos testes de software, visando uma melhoria no processo de preparação e execução de casos de testes de caixa preta, unitários, da fase de verificação.

A ferramenta proposta possibilita ao engenheiro de teste centralizar seus esforços na montagem da base de conhecimento, armazenando os novos casos de teste e/ou utilizando casos de testes existentes com a intenção de montar um conjunto de testes base para um novo ciclo de análise e geração de casos de testes.

A partir desta ferramenta proposta será possível gerenciar os resultados oriundos da execução dos testes como, também, efetuar análises entre os 
resultados esperados e os resultados obtidos podendo o engenheiro de teste atuar como oráculo. Este ponto é de suma importância para as atividades de análise e evidenciação dos resultados, tendo em vista que em algumas situações, os resultados obtidos passam despercebidos pelo testador.

\subsection{Justificativa}

A atividade de gerar casos de testes é muitas vezes lenta, cara, passível a falhas e também com um baixo índice de cobertura qualitativo de casos de testes. As principais razões que justificam o investimento em uma ferramenta de testes automatizada, segundo Papo (2009) são:

- Deteç̧ão imediata de defeitos em características ou funcionalidades do software: Estes defeitos costumam ser identificados rapidamente em testes unitários, mas possuem custo maior de análise e correção quando identificados apenas em um teste funcional de sistema.

- Melhor designe detalhado e arquitetura do software: os testes unitários forçam os desenvolvedores a melhorar seu design para que ele se torne mais estruturado e menos complexo.

- Melhor documentação do código do software: Cada teste unitário conta a história e os objetivos de um método.

- Diminuição do tempo de detecção e correção de manutenções corretivas: um conjunto de casos de testes unitários automatizados garante que uma mudança em um ou mais trechos de código não impacte outras funcionalidades.

Os resultados que a ferramenta proposta poderá alcançar são expressivos para a melhoria do processo de preparação e execução de casos de testes funcionais.

\section{$1.3 \quad$ Métodos de Trabalho}

Para atingir os objetivos propostos executou-se a seguinte atividade:

- Experimentos: Realização de estudo de caso e documentação dos resultados obtidos. Foram selecionados alguns projetos que envolveram 
desenvolvimento de software, em que foram desenvolvidas as especificações de requisitos, necessárias para a realização da inspeção dos artefatos de testes. Avaliação dos resultados obtidos e análise da eficácia dos processos de testes e de inspeção, utilizando as métricas previamente identificadas;

\subsection{Organização do Trabalho}

Este trabalho é composto por 6 capítulos.

O capítulo 1, Introdução, apresenta a motivação para a realização do trabalho, os objetivos, a metodologia desenvolvida e a descrição da estrutura do trabalho.

Os capítulos de 2 e 3, apresentam a revisão da literatura de Teste de Software, Inteligência computacional e de Testes Funcionais. O resultado da pesquisa bibliográfica realizada, formando o embasamento para o desenvolvimento do trabalho. Este capítulo discute os seguintes temas principais: Conceitos de Testes de Software, como: Casos de testes, Ambientes de testes, qualidade de software, Processo de Teste de software, TMM -Test Maturity Model, V-Model e técnicas de teste de software.

O capítulo 4 apresenta o modelo arquitetural da ferramenta e o processo de geração de casos de testes visando a formação da massa de dados para testes.

O capitulo 5, aborda sobre a aplicação prática dos conceitos estudados neste trabalho em uma ferramenta contendo os requisitos funcionais mínimos e necessários para a comprovação dos métodos estudados e que podem compor a ferramenta de fato.

O capítulo 6, Considerações Finais, apresenta a avaliação da realização deste trabalho, suas limitações, bem como propostas para o seu desenvolvimento no futuro. 


\section{TESTE DE SOFTWARE}

Os testes de software têm como principal objetivo o de assegurar que o software cumpra as especificações e atenda aos requisitos funcionais e não funcionais definidos no início do projeto do software.

Garantir padrões de qualidade do software, não é uma missão tão simples, nos quais vários fatores estão envolvidos para que se atinjam estes patamares de qualidade. Dentre estes fatores destacam-se:

- Fatores de Qualidade Operacional, caracterizado pela correção, eficiência ou desempenho, robustez, confiabilidade, usabilidade, utilidade e validade do software;

- Fatores de Qualidade de Revisão, que está relacionado com a manutenção, evolução e avaliação do software;

- Fatores de Qualidade de Transição, que estão relacionados com a instalação, reutilização e interação com outros produtos.

Assim como existem iniciativas para a criação de modelos de avaliação e melhoria do processo de desenvolvimento de software visando a Garantia da Qualidade de Software (GQS), como: Modelo de Maturidade (Capability Maturity Model - CMM), Modelo de Maturidade e Integração (Capability Maturity Model Integration - CMMI) e a norma ISO/IEC 15504 (Software Improvement \& Capability Determination -SPICE). Também existem iniciativas que visam garantir padrões de qualidade no processo de teste de software como a norma IEEE Std. 829/98, que regulamenta os padrões de documentos a serem utilizados em cada fase do processo de teste de software e o TMM (Testing Maturity Model) que é um modelo de qualidade do processo de testes baseado no CMM.

Elaborar os casos de testes é uma das atividades responsáveis pela garantia da qualidade do software, sendo diretamente ligada ao poder de abstração do Analista de Testes sobre o objeto do teste. Neste capítulo é apresentada a revisão da literatura das principais técnicas de teste de software, além de normas que são aplicadas nos processos de teste. 


\subsection{Conceitos de teste de software}

Testar software consiste na dinâmica de verificação do comportamento de um programa a partir de um conjunto finito de casos de testes, geralmente selecionados de forma adequada de um domínio de execuções infinitas, objetivando a verificação do comportamento esperado segundo a (IEEE Computer Society Professional Practies Committee, 2004). Nos quais os termos em itálico têm sua representação na Tabela 1.

Tabela 1 - Termos que representam o conceito de Teste de Software.

\begin{tabular}{ll}
$\begin{array}{c}\text { Termo em } \\
\text { itálico }\end{array}$ & \multicolumn{1}{c}{ Representação } \\
\hline Dinâmica & $\begin{array}{l}\text { Significa que os testes implicam na execução dos valores de } \\
\text { entrada do software (avaliação). }\end{array}$ \\
\hline Finito & $\begin{array}{l}\text { O mesmo em um simples programa, muitos casos de testes } \\
\text { são teoricamente possíveis, porém, testes exaustivos podem } \\
\text { durar meses ou até anos }\end{array}$ \\
\hline Selecionado & $\begin{array}{l}\text { Algumas técnicas de testes diferem, essencialmente, na } \\
\text { forma de seleção dos conjuntos de testes, e os engenheiros } \\
\text { de software precisam está cientes destas vastas diferenças } \\
\\
\text { de critérios de seleção que precisam ser produzidos } \\
\text { efetivamente. }\end{array}$ \\
\hline Esperados & $\begin{array}{l}\text { Significa que precisa ser possível, embora nem sempre seja } \\
\text { fácil decidir se o resultado observado da execução do } \\
\text { software é aceitável ou não. Caso contrário o esforço do } \\
\text { teste terá sido inútil. }\end{array}$ \\
\hline
\end{tabular}

A representação dinâmica também significa que os valores de entradas por si só nem sempre são suficientes para determinar um teste, visto que a complexidade e o não determinismo do software força uma reação a estes valores entrados e que podem assumir comportamentos diferentes ao esperado, dependendo do estado do software; 
Para a representação finita, os testes sempre implicam em um trade-off'entre os recursos e limitados aos prazos, e inerentes aos requisitos;

Um conceito mais formal de teste de software é encontrado em IEEE 610.12, de 1990. É o processo de operações de um software ou componente sobre condições específicas, observando ou gravando os resultados, e fazendo avaliações de alguns aspectos do software e componentes.

A aplicabilidade dos testes em um software é a maneira mais comum de verificar se ele atende a sua especificação e realiza o que o cliente (quem paga pelo software e o utiliza) deseja. Entretanto, os testes são apenas uma das várias técnicas de verificação e validação.

As falhas dos softwares são relativamente comuns. Na maioria dos casos, essas falhas causam inconveniências, mas não danos sérios. No entanto, segundo Charette (2007) "[..] em alguns sistemas, as falhas podem resultar em perdas econômicas significativas, danos físicos ou ameaças à vida humana".

A Tabela 2 apresenta alguns dos principais conceitos em testes de software conforme a IEEE 610.12:

Tabela 2 - Conceitos de Termos em Teste de Software.

\begin{tabular}{lll}
\hline Termo & \multicolumn{2}{c}{ Conceitos } \\
\hline Erro (error) & • A diferença entre um valor computado, observado, ou \\
& mensurado ou uma condição verdadeira, especificada, ou \\
& valores ou condições teoricamente corretas; \\
& - Um passo incorreto, processo, ou definição de dados; \\
& - Um resultado incorreto; \\
& - Uma ação humana que produz um resultado incorreto; \\
& - Um conceito errado, ou um mal-entendido do \\
\hline Defeito & - Um desenvolvedor em uma parte do software. \\
(fault) & hardware; em um dispositivo ou componente de \\
& Um passo incorreto, processo, ou definição de dados em \\
& um programa de computador. \\
\hline
\end{tabular}

\footnotetext{
${ }^{1}$ Trade-off: refere-se, geralmente, a perder uma qualidade ou aspecto de algo, mas ganhando em troca outra qualidade ou aspecto.
} 
- Um defeito é introduzido dentro do software resultando em um erro. É uma anomalia no software que pode causar comportamentos incorretos, em oposição as suas especificações.

\begin{tabular}{c|l}
\hline $\begin{array}{c}\text { Falha } \\
\text { (failure) }\end{array}$ & A incapacidade de um sistema ou componente de \\
& $\begin{array}{l}\text { executar suas funções internas solicitadas e descritas nos } \\
\text { requisitos. }\end{array}$ \\
\hline
\end{tabular}

Um erro pode representar:

[..] um engano ou uma má interpretação por parte do programador sobre uma ou várias partes do software Um programador pode não entender a notação do design, ou poderia escrever o nome de uma variável incorretamente o que representa um erro (BURNSTEIN, 2003, p. 20).

A Figura 1 representa a classificação de algumas terminologias para teste de software pelas quais um erro representa a manifestação oriunda da ação humana que causa problemas internos no software e são chamados de (bugs). Um (bug) pode levar a um defeito no produto. Um defeito, uma anomalia resultante de um (bug), pode gerar a incapacidade de uma unidade no desempenho de sua função, falhas funcionais.

Durante a execução de um componente de software ou sistema, um testador, um desenvolvedor ou um usuário observa que o software não produziu o resultado esperado. Em alguns casos um tipo particular de comportamento inapropriado indica que há certo tipo de falha presente. Segundo Burnstein (2003, p. 21) pode-se afirmar que "[..] este tipo de comportamento inapropriado pode ser apresentado como um sintoma de falha". 


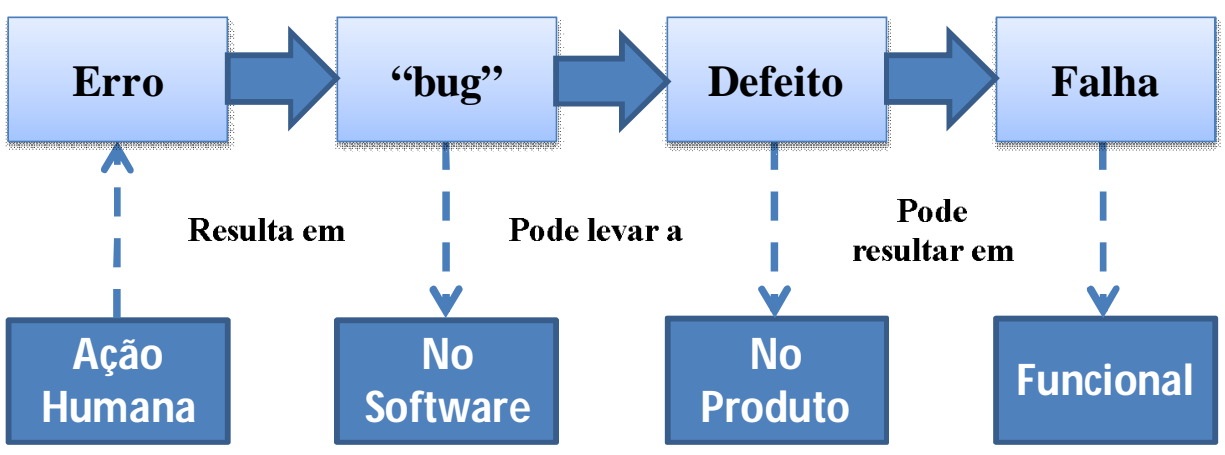

Figura 1 - Classificação de termos para teste de Software.

SPINA, E. Confiabilidade. São Paulo: USP, 2009. (Material de Aula).

Comportamentos incorretos podem produzir valores de saída incorretos, uma resposta incorreta em um componente de hardware ou uma imagem incorreta na tela. Durante o desenvolvimento as falhas são normalmente observadas pelos testadores, e defeitos são localizados e reparados pelos desenvolvedores. Falhas nos códigos fontes nem sempre produzem um defeito. De fato, software defeituoso pode funcionar por um longo período de tempo sem que demonstre qualquer tipo de falha.

Testadores precisam trabalhar em conjunto com os desenvolvedores para garantir a testabilidade do software.

\subsubsection{Casos de Testes}

Segundo Delamaro, Maldonado e Jino (2007) "[..] a forma mais comum de se detectar defeitos em uma parte do software é fazer com que o testador selecione um conjunto de dados de entrada e então execute o software com os dados de entrada sob um conjunto particular de condições". O testador precisa saber com antecedência quais são as saídas esperadas dos testes para o conjunto de dados de entrada e condições de execução. O testador empacota estas informações em itens, chamadas de Caso de Teste (Test Case).

Um Caso de Teste é um conjunto de dados de entrada de teste, condição de execução e resultados esperados. Um caso de teste é desenvolvido para um objetivo particular, como exercitar um ramo em um programa específico para verificar se obedece a um requisito específico.

Um caso de teste, no sentido prático, contém as seguintes informações (IEEE $610.12,1990)$ : 
- Um conjunto de dados de entrada para teste: Estes itens são os dados recebidos de uma origem externa ao código que está sendo testado. A origem externa pode ser entendida como um hardware, software, ou humana;

- Condições de execução: Estas condições são requeridas para a execução do teste, por exemplo, certo estado de um banco de dados, ou configuração de um dispositivo de hardware;

- Saídas esperadas: Estes são os resultados específicos a ser produzido por um dado código fonte sob teste.

As descrições acima especificam o mínimo de informação que pode ser encontrada em um caso de teste conforme a (IEEE 610.12, 1990). Uma empresa pode decidir que informações adicionais podem ser incluídas em um caso de teste para incrementar seus valores como um reuso de objeto, ou para prover informações mais detalhadas para os testadores e desenvolvedores.

A Figura 2, apresenta os casos de testes por meio dos elementos do domínio de entradas $D$ de um dado programa $P$, denotado por $D(P)$, e representa o conjunto de todos os valores possíveis que podem ser utilizados para executar $P$ e $x$ um elemento do conjunto $D$ e parâmetro de entrada de $P$. Em que $S$ representa a especificação do programa $P, \circ E(P)$ representa as especificações do programa $P$, quer seja na forma de documento ou qualquer outra forma que possa definir o seu comportamento.

Um caso de teste $T$, pode ser representado por um par ordenado $(x, S(x))$, tal que $x$ é um elemento do domínio $D$ e $S(x)$ é a saída esperada conforme a especificação $E$, utilizando o elemento $x$ como entrada.

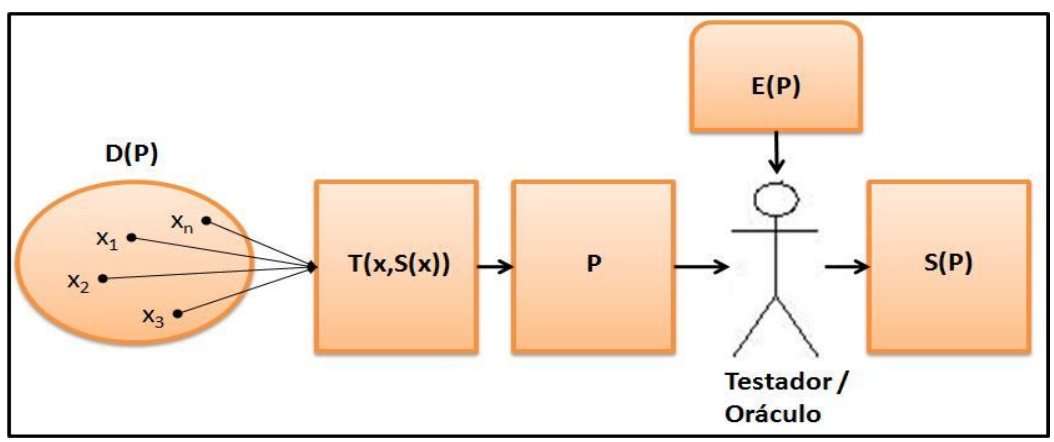

Figura 2 - Representação de um cenário típico de atividade de teste. Adaptado de Delamaro, Maldonado e Jino (2007, p. 3) 
As saídas $S(P)$ produzidas podem, conforme as especificações, resultar em sucesso ou falha, cabendo à figura do oráculo decidir se está ou não em conformidade com as especificações.

Um programa, ou um documento que produza ou especifica as saídas de um teste, pode servir como um oráculo Delamaro, Maldonado e Jino (2007). Exemplos incluem uma especificação (especialmente uma que contenha pré e pós-condição), um documento de desenvolvimento, e um conjunto de requisitos. Outras fontes são as suítes de testes de regressão (uma suíte de testes pode ser entendida como um conjunto de casos de testes). Estas suítes normalmente contem componentes com resultados corretos para versões anteriores do software.

\subsubsection{Ambiente de Teste (Test Bed)}

Um Ambiente de Teste (test bed) contém todos os elementos de hardware e softwares necessários para testar um componente ou um sistema de software. O ambiente de testes inclui, por exemplo, simuladores, emuladores, verificadores de memória, hardware experimental, ferramentas de software, e outros itens necessários para suportar a execução dos testes. Um ambiente de teste deve reproduzir fielmente o ambiente ao qual o software ou programa deverá funcionar.

\subsubsection{Qualidade de Software (Software Quality)}

A qualidade de software é composta pelos seguintes fatores: operação, transição e revisão e que podem impactar direta ou indiretamente no custo, planejamento e funcionalidades de um software. Estes fatores determinam o sucesso ou o fracasso de um produto de software em seus ambientes de uso.

A norma IEEE 610.12 (1990) conceitua qualidade de duas formas concisas, conforme abaixo:

- Qualidade relaciona o grau no qual um sistema, componente de sistema, ou processo que reúnam os requisitos especificados;

- Qualidade relaciona o grau no qual um sistema, ou componente de sistema, ou processo reúnem clientes ou mesmo necessidade de usuários, ou expectativas. 
Para determinar se um sistema, ou componente de sistema, ou processo é de alta qualidade basta que possua um conjunto de atributos de alta qualidade (Exatidão, confiabilidade, usabilidade, integridade, portabilidade, manutenibilidade e interoperabilidade). Estas são características que refletem qualidade. Para artefatos de software pode-se mensurar o grau para o qual possuem um dado atributo de qualidade com métricas de qualidade. Segundo Gao, Tsao e Wu (2003, p. 306) "existem dois grupos de métricas: métricas de produto e métricas de processo".

As métricas de produtos são destinadas a capturar a qualidade do produto de software. Um exemplo comumente utilizado de uma métrica de produto de software é o tamanho do software, normalmente mensurado pelo número de linhas de código $\left(\mathrm{LOC}^{2}\right)$.

As métricas de processos são usadas para medir a qualidade do processo de desenvolvimento. Dois exemplos de métrica de processo comumente utilizados são o tempo e o custo requerido para uma dada tarefa. Métricas de qualidade são um tipo especial de métrica.

A Tabela 3 mostra os atributos de qualidade e seus respectivos significados conforme a (ISO/IEC 9126-1, NBR, 2003).

Tabela 3 - Atributos de Qualidade.

\begin{tabular}{|c|c|}
\hline \multicolumn{2}{|r|}{ Atributos de Qualidade } \\
\hline Atributo & Significado \\
\hline Funcionalidade & $\begin{array}{l}\text { É a Capacidade do produto de software de prover funções } \\
\text { que atendam às necessidades explícitas e implícitas, quando } \\
\text { o software estiver sendo utilizado sob condições } \\
\text { especificadas.. } \\
\text { - Esta característica está relacionada com o que software } \\
\text { faz para atender às necessidades, enquanto que outras } \\
\text { características estão principalmente relacionadas a } \\
\text { quando e como ele atende às necessidades; } \\
\text { - Para as necessidades explícitas e implícitas nesta } \\
\text { característica, a nota da definição de qualidade em B.21 é }\end{array}$ \\
\hline
\end{tabular}

${ }^{2}$ LOC: Lines Of Code 


\begin{tabular}{|c|c|}
\hline & $\begin{array}{l}\text { aplicável; } \\
\text { - Para um sistema que seja operado por um usuário, a } \\
\text { combinação de funcionalidade, confiabilidade, usabilidade } \\
\text { e eficiência pode ser medida externamente pela qualidade } \\
\text { em uso. }\end{array}$ \\
\hline Confiabilidade & $\begin{array}{l}\text { Capacidade do produto de software de manter um nível de } \\
\text { desempenho especificado, quando usado em condições } \\
\text { especificadas. } \\
\text { - Em software não ocorre desgaste ou envelhecimento. As } \\
\text { limitações em confiabilidade são decorrentes de defeitos } \\
\text { na especificação de requisitos, projeto e implementação. } \\
\text { As falhas decorrentes desses defeitos dependem de como } \\
\text { o produto de software é usado e das opções de programa } \\
\text { selecionadas e não do tempo decorrido; } \\
\text { A definição de confiabilidade na ISO/IEC } 2382-14: 1997 \text { é } \\
\text { "A habilidade de uma unidade funcional executar uma } \\
\text { função requisitada...". Neste documento, funcionalidade é } \\
\text { somente uma das características de qualidade de } \\
\text { software. Portanto, a definição de confiabilidade foi } \\
\text { expandida para "manter um nível de desempenho } \\
\text { especificado..." no lugar de “...executar uma função } \\
\text { requisitada".. }\end{array}$ \\
\hline Usabilidade & $\begin{array}{l}\text { Relaciona o grau de esforço necessário para o aprendizado, a } \\
\text { operação, a preparação das entradas, e interpretação das } \\
\text { saídas do software. } \\
\text { - Alguns aspectos como funcionalidade, confiabilidade e } \\
\text { eficiência também afetarão a usabilidade, mas para os } \\
\text { propósitos da NBR ISO/IEC } 9126 \text { não são classificados } \\
\text { como usabilidade; } \\
\text { - Como usuários pode-se incluir operadores, usuários finais } \\
\text { e usuários indiretos que sejam dependentes ou estejam } \\
\text { sob influência do uso do software. Convém que a }\end{array}$ \\
\hline
\end{tabular}


usabilidade considere todos os diferentes ambientes de usuários que o software pode afetar. Como exemplos de ambientes a considerar pode-se incluir o ambiente no qual os usuários estão sendo preparados para uso do produto e o ambiente em que já se permite avaliação de resultados do uso do produto

\begin{tabular}{ll}
\hline Integridade & $\begin{array}{l}\text { Refere-se à capacidade do sistema para suportar os ataques } \\
\text { intencionais e acidentais.. }\end{array}$ \\
\hline Portabilidade & $\begin{array}{l}\text { Relaciona a habilidade do software em ser compilado ou } \\
\text { executado em diferentes ambientes. }\end{array}$
\end{tabular}

Manutenibilidade É o esforço necessário para fazer correções em um software

Interoperabilidade $\hat{E}$ o esforço necessário para ligar ou unir um sistema a outro.

Para Burnstein (2003, p. 24) "um outro atributo de qualidade que poderia ser mencionado é a testabilidade". Este atributo é mais interessante para desenvolvedores e testadores que para os clientes. Este atributo pode ser expresso de duas formas, conforme abaixo:

- A quantidade de esforço necessário para testar um software para garantir sua execução conforme os requisitos especificados (relacionado ao número de casos de testes necessários),

- A habilidade do software para revelar defeitos em condições de teste (algum software é projetado de forma que defeitos ficam bem escondidos em condições normais de testes).

Testadores precisam trabalhar com os analistas, projetistas e, desenvolvedores por todo o ciclo de vida do sistema de software para garantir que a testabilidade seja possível.

\subsubsection{O Processo de Software}

Um processo de software é um conjunto de atividades que leva à produção de um produto de software. Essas atividades que compõem o processo de software 
além de conterem o desenvolvimento do software propriamente dito como também contém a atividade de teste de software.

A atividade de Testes é composta por cinco fases como mostrado na Figura 3.

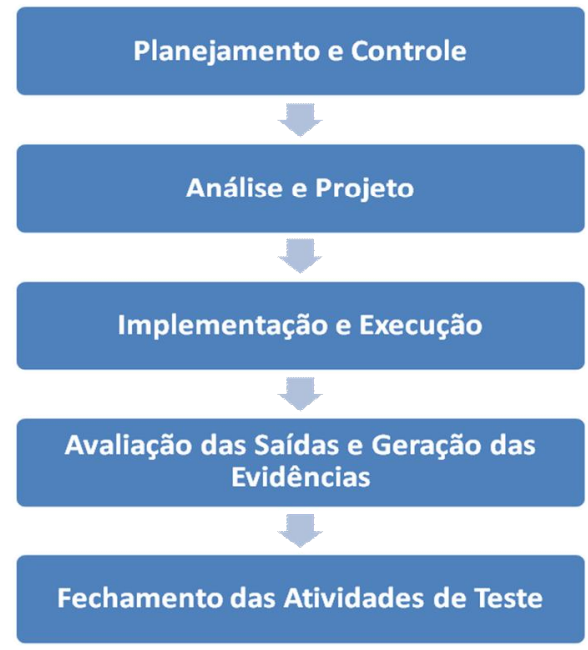

Figura 3 - Fases da Atividade de Teste de Software. Adaptado de Hambling et al (2007, p. 21).

- Planejamento e Controle: planejamento dos testes inclui definir qual o escopo dos testes a serem realizados. Nesta etapa também é elaborado um artefato denominado Plano de Testes de Software, que terá como entrada alguns artefatos de especificação de requisitos para atender os objetivos do software a ser testado. O Plano de Testes também inclui informações de como as atividades serão feitas; e quem as fará. Planejar testes é também definir os critérios de encerramento (os critérios de encerramento definem o quando os testes serão finalizados) dos testes. Controle define o que deve ser feito quando as atividades não estão acompanhando o que está planejado. É o processo pelo qual acompanha o progresso da atividade em relação ao planejamento;

- Análise e Projeto: análise e projeto estão relacionados com o detalhamento do que será testado, e como serão geradas as combinações das condições dentro dos casos de testes, objetivando que um dado número de casos de testes possa cobrir tantas condições quantas forem possíveis. As fases de análise e projeto representam uma ponte entre o planejamento e a execução; 
- Implementação e Execução: implementação e execução envolvem a execução dos testes, isto inclui, quando necessário, procedimentos de preparação (setup/tear-down) do ambiente para os testes. Inclusive a checagem do ambiente (test bed) antes do inicio dos testes. A execução representa a parte mais visível dos testes, entretanto a execução dos testes somente é possível mediante a agregação das demais fases que compõe o processo como um todo;

- Avaliação das Saídas e Geração das Evidências: os critérios de saídas são definidos durante o planejamento e antes da execução dos testes. Ao final da execução, a gerência de testes verifica se as diversas combinações das condições definidas na fase de análise e projeto estão sendo seguidos. Se as condições definidas nos casos de testes consigam atingir patamares de 85 por cento de cobertura dos requisitos testados ( 85 por cento de cobertura de todos os requisitos executados e com resultado satisfatório nos testes) caso atinja 75 por cento de cobertura, existem duas ações possíveis: modificar os critérios de testes, ou executar mais testes. Para gerar as evidências dos testes para os Stakeholders utiliza-se um sumário de testes. Os sumários de testes evidenciam os resultados obtidos com os testes em relação ao que foi planejado, com o que foi alcançado, destacando as diferenças e em particular o que não foi testado;

- Encerramento da atividade de testes: o encerramento dos testes concentra-se em garantir que todos os itens foram gerados, como: relatórios, defeitos foram fechados, e estes defeitos foram adiados para outras fases como devem ser feitas. A fase de encerramento dos testes é composta pelos seguintes itens:

- Assegurar que toda a documentação tenha sido gerada, e evidenciada conforme planejado;

- Fechar (armazenar em mídia) e arquivar o ambiente de teste, infraestrutura e os testware (ferramentas utilizadas nos testes) utilizados no teste;

- Registrar as lições aprendidas neste projeto de testes, para que sirva como referencial de melhorias para futuros projetos.

Apesar das atividades estarem em seqüência, não existe uma definição quanto a rigidez da ordem em que acontecem as atividades de teste. 
Um erro encontrado na execução de um teste pode, algumas vezes, ser resolvido com a adição de uma funcionalidade que não estava originalmente presente. Novas características precisam ser testadas, mesmo que a implementação esteja em andamento e funções mínimas estejam disponíveis para testes.

\subsubsection{Modelo de Maturidade de Testes (Test Maturity Model - TMM)}

O TMM foi desenvolvido pelo IIT (Illinois Institute of Technology) em 1996. Uma das principais razões da sua criação foi à ausência de modelos de maturidade que atendessem adequadamente às práticas do teste de software. O modelo foi desenvolvido para complementar as práticas de Engenharia de Software do CMM.

O TMM é um modelo de maturidade e a exemplo do CMM, também compreende um modelo de auditoria, baseado num questionário, no qual é verificado o nível de maturidade da área de TI em relação ao teste. O TMM contém etapas ou níveis ao qual passa uma organização com o seu processo que evolui de um teste ad-hoc e não gerenciado para um que seja gerenciado, definido, medido, e otimizável. Burnstein (2003, p. 548) evidencia a estrutura interna do TMM "[..] é rica em práticas de testes que podem ser aprendidos e aplicados de forma sistemática para apoiar um processo de qualidade de teste que melhora em passos incrementais [..]". Há cinco níveis do TMM que prescrevem uma hierarquia de maturidade e um caminho evolucionário para testar a melhoria de processos. As características de cada nível são descritas em termos de testes de capacidade de metas organizacionais, e as responsabilidades para as pessoas chave no processo de teste, como os gerentes, programadores, testadores e usuários/clientes.

A estrutura do TMM "[..] é baseada no modelo CMM que adota a divisão por níveis" (Burnstein, p. 552, 2003). O TMM consiste em cinco níveis de maturidade que reflete um aumento do grau de maturidade do Processo de Teste. Para cada nível de maturidade, um número de áreas de processo é definido. Uma área de processo é um grupo de atividades relacionadas com o Processo de Teste. Quando estas atividades são executadas adequadamente, elas contribuirão para melhoria do Processo de Teste. Os cinco níveis do TMM poderão dar suporte a uma organização para determinar a maturidade do seu Processo de Teste e identificar os próximos 
passos de melhoria que são necessários para atingir um alto nível de maturidade do teste. Os cinco níveis do TMM são ilustrados na abaixo:

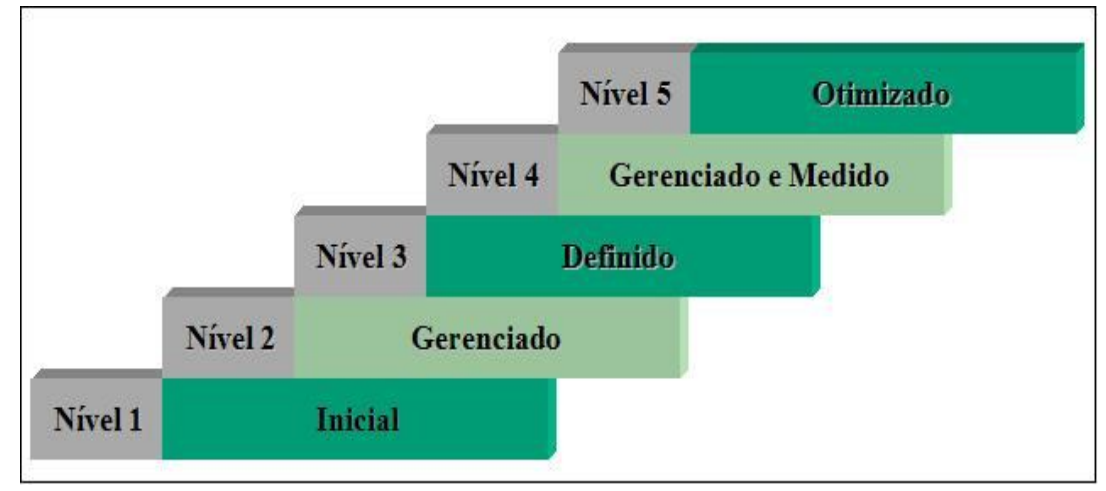

Figura 4 - Níveis de Maturidade do TMM Adaptado de Burnstein (2003, p. 13).

- Nível 1: neste nível não há diferenças entre teste e depuração. O processo de teste é caótico, indefinido e é considerado parte do processo de depuração. A empresa normalmente não fornece um ambiente estável para suporte ao processo. O sucesso depende do esforço e competência das pessoas da envolvidas com os testes. Os testes são desenvolvidos de forma ad-hoc após a fase de codificação do software;

- Nível 2: o teste mostra que o software funciona. O teste se torna um processo gerenciado e claramente separado do debug. O processo é refletido e disciplinado pela maturidade do nível 2 ajudando a assegurar as práticas existentes. De qualquer forma, o teste é sempre entendido pelo stakeholder ${ }^{3}$ como uma fase de projeto que seguinte a codificação. O nível 2 é também conhecida como fase de definição, e tem como objetivos a institucionalização dos métodos e técnicas básicas de testes, iniciar um processo de planejamento de testes, e desenvolver os objetivos do teste e do debug. As áreas de processo no TMM nível 2 são: Política e estratégia de testes; planejamento de testes, monitoramento e controle de testes, projeto e execução de testes, e ambiente de testes.

- Nível 3: o teste mostra que o software não funciona. Está completamente integrado no ciclo de vida do software com marcos associados. O

\footnotetext{
${ }^{3}$ Stakeholder é qualquer pessoa ou organização que tenha interesse ou seja afetado pelo projeto.
} 
planejamento de testes é feito em um estágio anterior do projeto, por exemplo: durante a fase de requisitos, implicando em um plano de testes mestre. O desenvolvimento de um plano de testes mestre constrói as características do planejamento dos testes e obtendo os compromissos no nível 2. A organização dos conjuntos de padrões de processos de testes, os quais são base para 0 nível 3 , são estabelecidos e melhorados periodicamente. O nível 3 é também conhecido como fase de integração, e tem como objetivos o controle e a monitoração do processo de testes, integração dos testes no ciclo de vida do software, estabelecer um programa de treinamento técnico, estabelecer uma organização nos testes de software.

- Nível 4: o teste não prova coisa alguma, mas reduz os riscos do software não funcionar com valores aceitáveis. A organização do teste é perfeitamente definida, processo bem formado e mensurável. No nível 4 de maturidade, a empresa e os projetos estabelecem objetivos quantitativos para a qualidade do produto e desempenho do processo e os utiliza como critérios para gerenciá-los. O nível 4 é também conhecido como fase de gerenciamento e medição, e tem como objetivos a avaliação da qualidade do software, o estabelecimento de um programa para mensurar (medir) os testes, estabelecer um programa de ampla revisão organizacional. As áreas de processo no TMM nível 4 são: Dimensionar o Software, avaliar a qualidade do produto e avançar nos pontos de revisões.

- Nível 5: o teste não é uma ação. É uma disciplina mental de resultados do software com baixo risco e sem muito esforço de teste.

\subsubsection{O Modelo em V (V-Model)}

O V-model ou Modelo em V foi desenvolvido para solucionar alguns problemas existentes na abordagem de desenvolvimento de software tradicional ou em cascata. Defeitos foram sendo encontrados também no final do ciclo de vida, em virtude dos testes de software não estarem envolvidos até o final do projeto. $O$ modelo em $\mathrm{V}$ orienta que o teste de software deve começar o mais cedo possível no ciclo de vida, que é um dos princípios fundamentais de testes de software 
estruturados. O modelo em $\mathrm{V}$ também mostra que o teste não é apenas uma execução baseada em atividades. Há uma variedade de atividades que precisam ser executadas antes do final da fase de codificação. Essas atividades devem ser realizadas em paralelo com atividades de desenvolvimento, e testadores precisam trabalhar em conjunto com os desenvolvedores e analistas de negócios para que eles possam realizar essas atividades e tarefas e produzir um conjunto de resultados de teste. Os produtos gerados pelos programadores e analistas de negócios durante o desenvolvimento são a base de teste em um ou mais níveis. Uma boa prática é ter testadores envolvidos ainda mais cedo, durante a revisão do projeto. O modelo em $\mathrm{V}$ é um modelo que ilustra como as atividades de teste (verificação e validação) podem ser integradas em cada fase do ciclo de vida.

O modelo em $\mathrm{V}$ esta dividido em quatro níveis de teste, que estão dispostos na Tabela 4.

Tabela 4 - Níveis de Teste do Modelo em V.

\begin{tabular}{|c|c|}
\hline Nível de Teste & Descrição \\
\hline $\begin{array}{l}\text { Teste de } \\
\text { Componentes }\end{array}$ & $\begin{array}{l}\text { Caracteriza-se pela busca por defeitos e verifica as } \\
\text { funcionalidades dos componentes do software (módulos, } \\
\text { programas, objetos, classes) que são testados } \\
\text { separadamente; }\end{array}$ \\
\hline $\begin{array}{ll}\text { Teste } & \text { de } \\
\text { integração } & \end{array}$ & $\begin{array}{l}\text { Visa testar interfaces entre componentes, interações para } \\
\text { diferentes partes de um sistema como um sistema } \\
\text { operacional, arquivo de sistema e hardware ou as interfaces } \\
\text { entre eles; }\end{array}$ \\
\hline $\begin{array}{l}\text { Teste } \\
\text { Sistema }\end{array}$ & $\begin{array}{l}\text { Relaciona-se ao comportamento de todo produto/sistema } \\
\text { conforme definido pelo escopo de desenvolvimento de um } \\
\text { projeto ou produto. O principal foco do teste de sistema é a } \\
\text { verificação frente aos requisitos especificados; }\end{array}$ \\
\hline $\begin{array}{l}\text { Teste } \\
\text { aceitação }\end{array}$ & $\begin{array}{l}\text { Teste de aceitação diz respeito às necessidades do usuário, } \\
\text { requisitos, e processos de negócios realizados para } \\
\text { determinar se aceita ou não o sistema. }\end{array}$ \\
\hline
\end{tabular}

Dentre as atividades de Garantia da Qualidade de Software (GQS), encontram-se as atividades de Verificação, Validação e Teste (VV\&T). Verificação, 
consiste em atividades que garantam que o software implementa corretamente uma função específica e validação refere-se às atividades que garantam que o software construído está de acordo com os requisitos do cliente Pressman (2005). Os testes podem ser realizados em três fases segundo BEIZER, 1990 apud PRESSMAN, 2005, conforme Tabela 5:

Tabela 5 - Fases de Teste de Software

\begin{tabular}{ll}
\hline $\begin{array}{l}\text { Fase de } \\
\text { Teste }\end{array}$ & \multicolumn{1}{c}{ Descrição } \\
\hline $\begin{array}{l}\text { Teste de } \\
\text { Unidade }\end{array}$ & $\begin{array}{l}\text { Cada módulo do software é testado separadamente com o } \\
\text { objetivo de identificar erros de lógica e de implementação. Como } \\
\text { há inter-relação entre os módulos, torna-se necessária a criação } \\
\text { de pseudocontroladores (drivers) e/ou pseudocontrolados } \\
\text { (stubs). }\end{array}$ \\
\hline $\begin{array}{l}\text { Teste de } \\
\text { Integração }\end{array}$ & $\begin{array}{l}\text { Representa uma progressão ordenada de testes em que o } \\
\text { elementos individuais de software, os elementos de hardware, ou } \\
\text { ambos sejam combinados e testados até que todo o sistema } \\
\text { tenha sido integrado; }\end{array}$ \\
\hline Teste de & $\begin{array}{l}\text { Teste do sistema completo: Nessa fase, o objetivo é garantir a } \\
\text { funcionalidade correta da combinação do software com os } \\
\text { demais elementos do sistema (hardware e banco de dados, por } \\
\text { exemplo). }\end{array}$ \\
\hline
\end{tabular}

Em teste de unidade os pseudocontroladores têm a função de controlar o teste do módulo, ativando-o e fornecendo os dados de testes definidos pelo testador. Os pseudocontrolados têm a função de simular os módulos que são chamados pelo módulo sob teste.

No item 2.2 deste capítulo, conceituaram-se as terminologias: "erro", "falha" e "defeito", com a finalidade de contextualizar este trabalho. 


\subsubsection{Técnicas de Teste de Software}

As três principais abordagens para os testes de software são: a funcional, a estrutural e a baseada em mutações ou erros. Este trabalho é focado nas técnicas de testes referentes à abordagem funcional.

O teste funcional, também conhecido como teste caixa-preta, consiste no teste de um programa considerando-o como um módulo em que apenas os dados de entrada e as saídas produzidas podem ser visualizados. Os casos de teste são extraídos da especificação do software com o intuito de que as suas funcionalidades sejam verificadas independentemente dos aspectos de implementação.

Casos de teste são criados para identificar as funcionalidades que o programa deve realizar.

O teste funcional consiste na geração dos casos de teste a partir da especificação do software. Desse modo, é importante que a especificação seja consistente quanto aos requisitos do usuário final. Caso contrário, os testes serão improdutivos. Alguns exemplos de critérios da técnica de teste funcional são apresentados a seguir.

- Particionamento em Classe de Equivalência: o critério de particionamento em classe de equivalência divide o domínio de entrada de um programa em um número finito de classes de dados válidas (entradas válidas para o programa) e inválidas (demais entradas). A partir dessa divisão, os casos de teste são extraídos com a suposição de que um teste realizado com um caso de teste de uma classe seja equivalente ao teste realizado com qualquer outro caso de teste da mesma classe, ou seja, um elemento de uma classe revela os mesmos erros que qualquer outro elemento dessa mesma classe revelaria. Desse modo, um número menor de casos de teste é selecionado da seguinte forma: seleciona-se um caso de teste distinto para cada classe inválida e um conjunto mínimo de casos de teste representativos das classes válidas.

- Análise do valor limite: o critério de análise do valor limite consiste em uma extensão ao particionamento em classe de equivalência, pois os elementos que se encontram nos "limites" das classes são selecionados. Em vez de 
selecionar os elementos do interior da classe, os elementos que se concentram nas "fronteiras" das classes são escolhidos, pois os erros tendem a ocorrer nesses pontos Pressman (2005, p. 464). As saídas também são particionadas em classes e casos de teste são selecionados para resultar em valores que estão nos limites dessas classes.

Grafo de causa-efeito: o critério de grafo de causa-efeito considera as condições dos dados de entrada. As condições de entradas (causas) e as ações (efeitos) são identificadas para a construção de um grafo. Uma tabela de decisão é montada, a partir do grafo, para a posterior derivação dos casos de teste.

Testes estruturais ou testes de caixa branca objetivam utilizar a estrutura interna do programa para a derivação dos casos de testes. Desse modo, as características de implementação devem ser conhecidas. Devido à natureza dos erros existentes em um programa, o teste estrutural é visto como complementar ao teste funcional. Os caminhos lógicos do software são testados, fornecendo-se casos de teste que põem à prova tanto conjuntos específicos de condições e/ou laços de repetição como pares de definições e usos de variáveis. O critério pertencente à técnica estrutural é classificado com base na complexidade, no fluxo de controle de dados.

O teste de mutação ou análise de mutantes, como também é conhecido, é um critério de teste da técnica baseada em defeitos. Nessa técnica são utilizados defeitos típicos do processo de implementação de software para que sejam derivados os requisitos de teste. Neste, o programa que está sendo testado é alterado diversas vezes, criando-se um conjunto de programas alternativos ou mutantes, como se defeitos estivessem sendo inseridos no programa original. $O$ trabalho do testador é escolher casos de testes que mostrem a diferença de comportamento entre o programa original e os programas mutantes.

O escopo da ferramenta proposta para geração automática de casos de testes de software funcionais visa gerar casos de testes para testar APl's desenvolvidas para atender particularidades de um sistema de informação, como APl's voltadas a encapsular comandos de conexão a bancos de dados, comandos 
de bancos de dados, comunicação com dispositivos seriais ou paralelos. A ferramenta proposta não está preparada para gerar testes de API's do sistema operacional ou no contexto de desenvolvimento web.

A técnica de teste de software funcional inicialmente utilizada na ferramenta é o particionamento de classe de equivalência, para os casos em que o domínio de valores de entradas forem numéricos.

\section{$2.2 \quad$ Testes funcionais}

As técnicas de testes de software têm o objetivo de fornecer argumentos lógicos para a elaboração de casos de testes com relação ao software a ser testado.

essas técnicas fornecem diretrizes sistemáticas para projetar testes [1] que exercitam a lógica interna e as interfaces de cada componente de software, e [2] exercitam os domínios de entradas e saídas do programa para descobrir erros na função, no comportamento e no desempenho do programa. Pressman (2006, p.315)

A técnica de particionamento em classe de equivalência, na década de 70 , considerava apenas o domínio de entrada do software e posteriormente passou a considerar também o conjunto de saídas.

Esta técnica considera um conjunto de estados válidos ou inválidos para 0 domínio de entrada do software. Entende-se por conjunto de estados válidos ou inválidos como as condições que satisfazem ou não um dado conjunto de entradas em um software.

Segundo Delamaro, Maldonado e Jino (2007, p. 12) o particionamento por classe de equivalência pode ser definido conforme as seguintes diretrizes:

- Se a condição de entrada especifica um intervalo de valores, define-se uma classe válida e duas inválidas;

- Se a condição de entrada especifica uma quantidade de valores, define-se uma classe válida e duas inválidas;

- Se a condição de entrada especifica um conjunto de valores determinados e o programa pode manipulá-los de forma diferente, 
define-se uma classe válida para cada um desses valores e uma classe inválida com outro valor qualquer;

- Se a condição de entrada especifica uma situação especifica, define-se uma classe válida e uma inválida.

Para exemplificar a aplicação desta técnica pode-se considerar um algoritmo, Figura 5, que, dado um conjunto de valores de entrada, numéricos e inteiros, retornar o tipo de triângulo (escaleno, retângulo, eqüilátero, acutângulo, obtusângulo e isosceles).

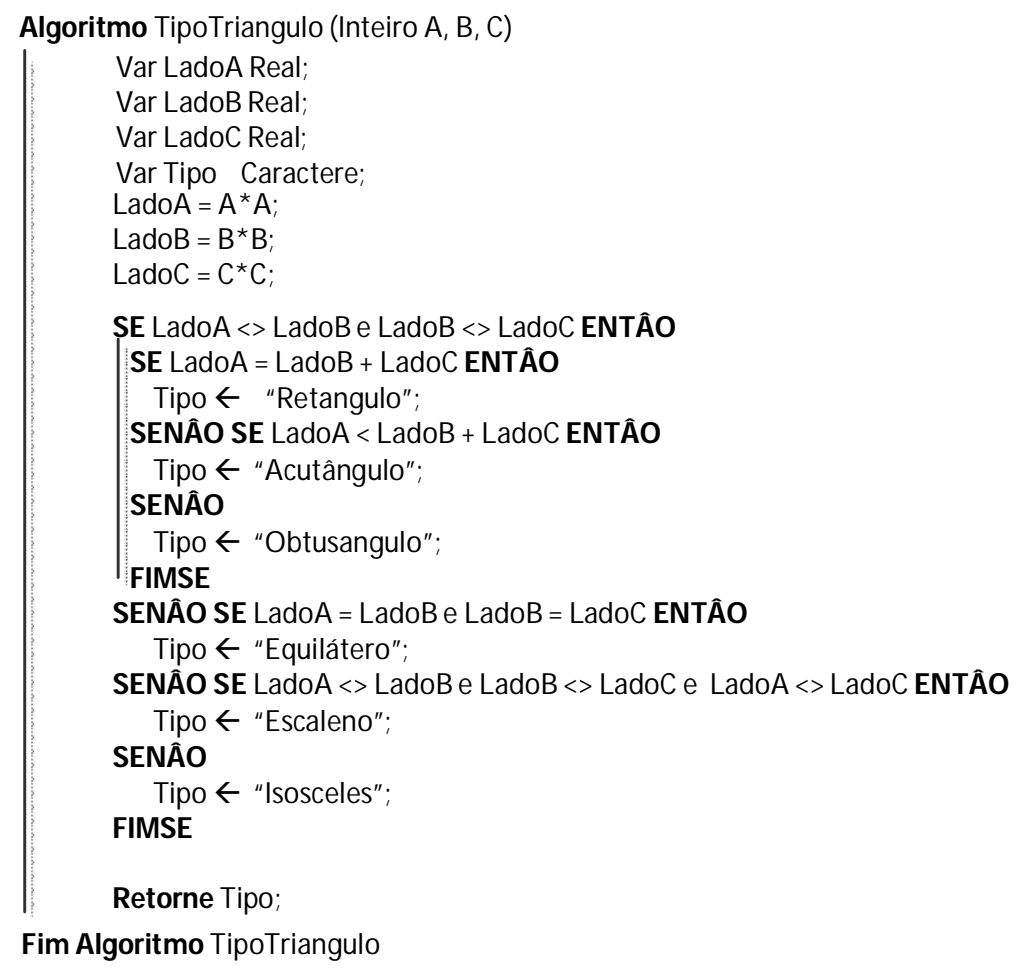

Figura 5 - Algoritmo que retorna o tipo de triângulo.

Conforme a Tabela 6 as variáveis de entrada que representam os valores dos lados do triângulo são definidos como: A, B e C.

Os valores esperados como retorno podem ser representados pelos tipos de triângulos. 
Tabela 6 - Variáveis de entrada e classes válidas e inválidas.

\begin{tabular}{ccc}
\hline $\begin{array}{c}\text { Variáveis de } \\
\text { Entrada }\end{array}$ & $\begin{array}{c}\text { Classe de equivalência } \\
\text { válida }\end{array}$ & $\begin{array}{c}\text { Classe de equivalência } \\
\text { inválida }\end{array}$ \\
\hline A & $1 \leq A \leq 10$ & $A<1$ e $A>10$ \\
\hline$B$ & $1 \leq B \leq 10$ & $B<1$ e $B>10$ \\
\hline C & $1 \leq C \leq 10$ & $C<1$ e $C>10$ \\
\hline
\end{tabular}

Fonte: Autor

Os critérios utilizados para determinar as classes de valores válidos ou inválidos, apresentados na Tabela 7, especificam, também, as condições de existência de cada tipo de triângulo.

Tabela 7 - Condições de existência para cada tipo de triângulo.

\begin{tabular}{cc}
\hline Tipo de Triângulo & Condições de existência \\
\hline Eqüilátero & $\mathrm{A}=\mathrm{B}=\mathrm{C}$ \\
\hline Isósceles & $\mathrm{A}=\mathrm{B}$ e $\mathrm{B} \neq \mathrm{C}$ \\
\hline Escaleno & $\mathrm{A} \neq \mathrm{B}, \mathrm{B} \neq \mathrm{C}$ e $\mathrm{A} \neq \mathrm{C}$ \\
\hline Retângulo & $\mathrm{A}^{2}=\mathrm{B}^{2}+\mathrm{C}^{2}$ \\
\hline Obtusângulo & $\mathrm{A}^{2}>\mathrm{B}^{2}+\mathrm{C}^{2}$ \\
\hline Acutângulo & $\mathrm{A}^{2}<\mathrm{B}^{2}+\mathrm{C}^{2}$ \\
\hline
\end{tabular}

Fonte: Autor

A Tabela 8 evidencia alguns casos de testes para o algoritmo da Figura 5.

Tabela 8 - Casos de testes para o critério particionamento de equivalência.

\begin{tabular}{cccc}
\hline \multicolumn{3}{l}{ Variáveis de Entrada } & \multirow{2}{*}{ Saída Esperada } \\
\cline { 1 - 3 } A & B & C & \\
\hline $\mathbf{3}$ & 3 & 5 & Triângulo Isósceles \\
\hline $\mathbf{2}$ & 1 & 1 & Não há condição prevista \\
\hline $\mathbf{3}$ & 3 & 3 & Triângulo Eqüilátero \\
\hline $\mathbf{0}$ & 1 & 0 & Valor fora da faixa válida \\
\hline
\end{tabular}

Fonte: Autor 
Os resultados apurados com este conjunto de valores aplicados ao algoritmo que determina o tipo de triângulo são:

- considerando que o intervalo de valores válidos ou inválidos na Tabela 6 é atendido com êxito;

- considerando que uma determinada faixa de valores válidos de entrada $(A=2, B=1$ e $C=1)$ não está coberta pelo algoritmo e com isto não retorna um valor conhecido pelos resultados esperados.

Considerando que as faixas de valores referentes à $(A=0, B=1$ e $C=0)$ e $(A=2$, $B=1$ e $C=1$ ) não produziram resultados conhecidos ou esperados pelas condições de existência constantes na Tabela 7, pode-se inferir que existem falhas no algoritmo no que diz respeito á análise de valores que não representam um triangulo.

\subsection{Considerações Parciais}

Neste capítulo foram apresentados os principais conceitos relacionados a Teste de Software, Técnicas e processo de teste de software. Os princípios de qualidade de software como os atributos de qualidade e o V-model e TMM são importantes para o entendimento do processo com o intuito de identificar possíveis falhas e conseqüentemente propor melhorias.

Estes conceitos, juntamente com os dos próximos capítulos formam a base para a definição da ferramenta proposta. 


\section{INTELIGÊNCIA COMPUTACIONAL}

Segundo Rezende e Prati (2005, p. 13), "há cerca de vinte anos os sistemas baseados em conhecimento vem sendo amplamente utilizados nas áreas comerciais e industriais como também na área acadêmica". Esses sistemas devem ser utilizados quando a formulação genérica do problema a ser resolvido computacionalmente é complexa (tipicamente combinatória) e quando existe uma grande quantidade de conhecimento específico do domínio sobre como resolvê-lo. O que leva a inferir que uma boa indicação a respeito do uso desta tecnologia é a existência de um especialista humano capaz de solucionar o problema.

Os sistemas baseados em conhecimento são um importante avanço tecnológico na resolução computacional de problemas que antes só eram resolvidos por seres humanos.

Neste capítulo, serão apresentados conceitos de Inteligência Computacional e técnicas computacionais baseadas na aquisição do conhecimento, como aprendizado de conjunto de regras, lógica fuzzy, Redes Neurais Artificiais (RNA) e árvores de decisão.

\subsection{Inteligência Computacional}

Pode-se dizer que a Inteligência Computacional corresponde a uma linha de pesquisa situada no contexto da Ciência da Computação e tem como objetivo desenvolver, avaliar e aplicar técnicas na criação de sistemas inteligentes.

Os sistemas inteligentes representam sistemas que imitam aspectos do comportamento humano, tais como: aprendizado, percepção, raciocínio, evolução e adaptação. Também pode ser entendida como o estudo da habilidade do homem em resolver problemas complexos por meio de sistemas computacionais.

O objetivo das pesquisas em Inteligência Computacional é capacitar o computador a executar funções que são desempenhadas pelo ser humano usando o conhecimento e o raciocínio, conforme (REZENDE e PRATI, 2005).

Para o perfeito entendimento da ligação entre o conhecimento com os diferentes meios e tecnologias para seu registro e processamento, faz-se necessário uma distinção entre dado, informação e conhecimento no qual o dado, é um 
elemento puro e quantificável sobre um determinado evento; a informação representa o dado analisado e contextualizado; a interpretação de um conjunto de dados e o conhecimento que se refere à habilidade de criar um modelo mental que descreva o objeto e indique as ações a serem implementadas e as decisões a serem tomadas.

\subsection{Lógica Fuzzy}

A lógica fuzzy, segundo Rezende e Prati (2005, p. 170), é uma lógica não clássica, criada por Zadeh em 1965, para tratar do aspecto vago da informação. Esta lógica é capaz de tratar informações do tipo vaga e/ou imprecisa e pode ser vista como uma generalização da lógica clássica dos conjuntos.

No modelo clássico, um determinado elemento pertence ou não a um dado conjunto. Nos conjuntos difusos um determinado elemento pode pertencer parcialmente ou totalmente a um determinado conjunto. Na lógica fuzzy, o grau de pertinência de um elemento é modelado como um valor pertencente ao intervalo $[0,1]$.

A função característica, ou função membro, é definida pela atribuição de valores Zero ou Um para cada elemento do universo de discurso, $U$, discriminando assim, os elementos e os não-elementos do conjunto crisp.

Klir e Yuan (1995, p. 11) definem as funções membros como: "uma função que pode generalizar de tal forma que os valores atribuídos aos elementos do conjunto universo podem representar um valor dentro de um intervalo especificado e indicar o grau de adesão". Neste contexto pode-se definir as seguintes notações para as funções membro:

$$
\mu_{A}: X \rightarrow[0,1]
$$

Desta forma, a notação (1) é composta por $\mu_{A}$, que representa a função membro, e X o elemento do conjunto crisp que está mapeado no intervalo $[0,1]$.

Um outro conceito pode ser encontrada em Rezende e Prati (2005, p. 170) no qual uma função membro de um conjunto fuzzy e é vista como a dependência do significado lingüístico definido para este conjunto e de sua interpretação no contexto do universo de discurso utilizado. Desta forma, na lógica fuzzy, o grau de 
pertinência de um elemento em relação a um conjunto definido por uma função característica real, que assume como valor qualquer número pertencente ao intervalo real fechado $[0,1]$. A representação algébrica é mapeada por: $\mu_{\mathrm{y}}(\mathrm{x}): \mathrm{U} \rightarrow$ $[0,1]$.

A função membro representa graficamente a amplitude do envolvimento de cada elemento de entrada. Para Kaehler (2010), as funções membro associam "um coeficiente de ponderação de cada uma das entradas que são processadas, define a sobreposição funcional entre os insumos e, finalmente, determina uma resposta de saída".

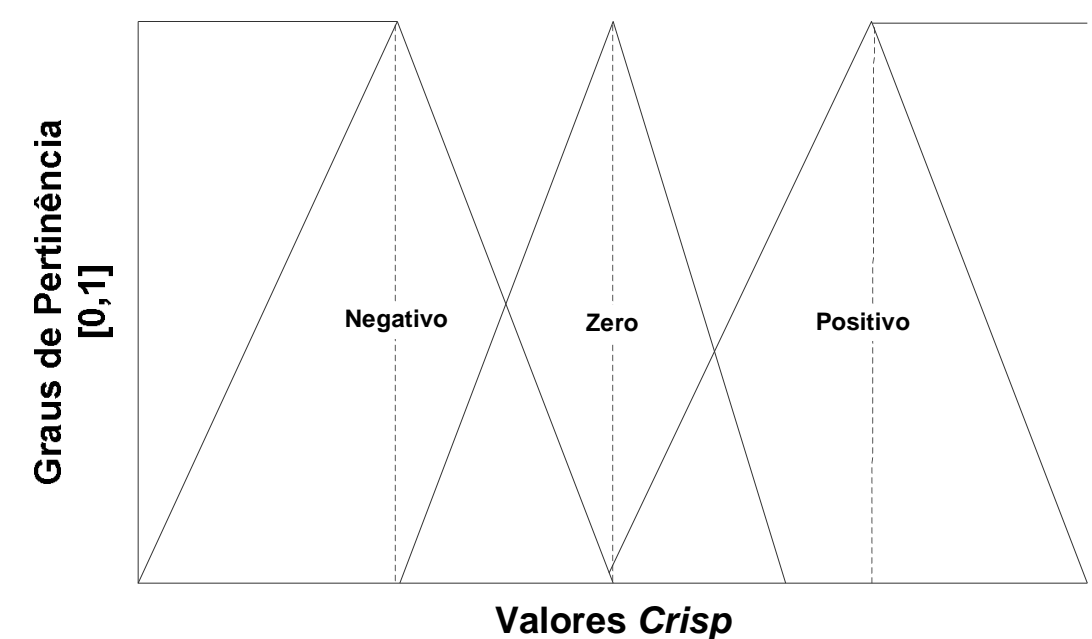

Figura 6 - Representação das funções membro. Adaptado de Kaehder (2010).

Algumas características da função membro, como a forma triangular e trapezoidal são evidenciadas na Figura 6, ressaltando-se que estas são consideradas as mais utilizadas devido à simplicidade matemática. Não é objetivo deste estudo detalhar as funções membros.

\subsubsection{Variáveis lingüísticas}

Segundo Zadeh (1973, p. 29), "uma variável lingüística é caracterizada por uma quíntupla $(x, T(x), U, G, M)$ na qual $x$ é o nome da variável; $T(x)$ é o termo do conjunto de $x$, que é, o conjunto de nomes de valores lingüísticos de $x$ com cada valor iniciando um numero fuzzy definido em U; G é uma regra sintática para 
generalizar os nome dos valores de $x$; e $M$ é uma regra semântica associada com cada valor e seu significado".

Uma variável lingüística admite como valores apenas expressões lingüísticas, como "bom", "muito bom", "grande" entre outros. As variáveis lingüísticas podem ser utilizadas dependendo basicamente da definição das propriedades sintáticas e semânticas que vão reger o comportamento do sistema de conhecimento fuzzy. Segundo Rezende e Prati (2005, p. 178) "[..] uma propriedade sintática define o formato em que serão armazenadas as informações lingüísticas fuzzy".

As variáveis lingüísticas proporcionam a criação da base de conhecimento contendo sentenças estruturadas, sistematizando os processos de armazenamento, busca e processamento de dados existentes que:

As propriedades semânticas especificam de que modo pode ser extraído e processado o conhecimento, armazenando-o na forma de declarações condicionais fuzzy, ou regras de produção fuzzy, contido na estrutura definida pelas propriedades sintáticas .(Rezende e Prati,2005, p. 178)

\subsubsection{Regras de Produção Fuzzy}

Uma base de conhecimento fuzzy é a forma mais comum de armazenamento de informações representadas por meio de regras de produção fuzzy. Uma regra de produção geralmente é formada por duas partes:

\section{If <antecedente> then <conseqüente>}

Os antecedentes são compostos por um conjunto de condições que, quando satisfeitas, mesmo que parcialmente, determinam o processamento do conseqüente da regra por meio de um mecanismo de inferência fuzzy.

Os conseqüentes são compostos por um conjunto de ações ou diagnósticos que são gerados com o disparo das regras (antecedentes). Os conseqüentes das regras disparadas são processados em conjunto para gerar uma resposta determinística para cada variável de saída do sistema.

Seguindo o exemplo da Temperatura, pode-se montar uma base de regras utilizando uma simples tabela, conforme Tabela 9: 
Tabela 9 - Valores de antecedentes e conseqüentes

\begin{tabular}{|c|c|}
\hline Faixa de Temperatura & $\begin{array}{c}\text { Variável } \\
\text { Lingüística }\end{array}$ \\
\hline if Temperatura menor que $5^{\circ}$ then & $\bar{E}$ muito baixa \\
\hline if Temperatura maior que $5^{\circ}$ e menor que $15^{\circ}$ then & É baixa \\
\hline if Temperatura maior que $15^{\circ}$ e menor que $25 \circ$ then & $\bar{E}$ agradável \\
\hline if Temperatura maior que $25^{\circ}$ e menor que $35^{\circ}$ then & É alta \\
\hline if Temperatura maior que $35^{\circ}$ then & É muito alta \\
\hline
\end{tabular}

Fonte: Autor

\subsubsection{Modelo de Inferência de Mamdani}

Na sessão 3.2.1 conceituou-se que a semântica é responsável por definir para o mecanismo de inferência como serão processados os antecedentes, quais serão os indicadores de disparo das regras e quais operadores serão utilizados sobre os conjuntos fuzzy existentes para executar o processamento de conhecimento.

Na década de 70, Mamdani (1974 apud Zadeh, 1990) propôs um método de inferência fuzzy que foi por muitos anos um padrão para utilização dos conceitos da lógica fuzzy em processamento de conhecimento. As regras de produção, neste modelo, possuem relações fuzzy tanto em seus antecedentes como em seus conseqüentes. Uma regra típica para o modelo de Mamdani é dado por: if <antecedente> and <antecedente $\mathrm{N}>$ then <conseqüente>, utilizando o exemplo da sessão anterior (temperatura), a regra de Mamdani assumira a seguinte notação: if Temperatura $=$ AumentandoMuito and Pressão $=$ MuitoAlta then PerigodeExplosão = Grande.

A Figura 7 apresenta uma máquina de inferência recebendo valores escalares, transformando-os em valores fuzzy por meio de um módulo de transformação. 


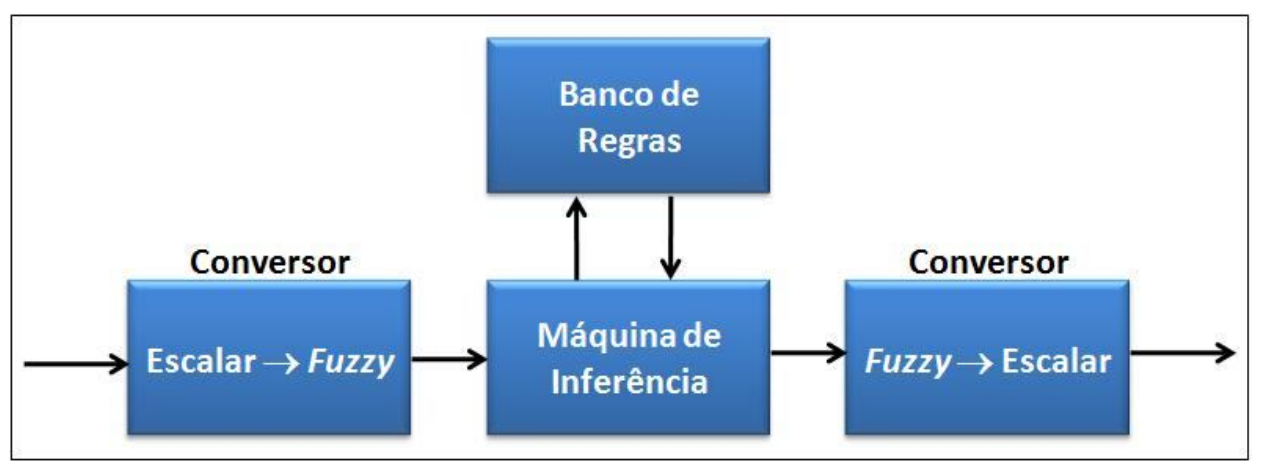

Figura 7 - Representação de um modelo de inferência de Mamdani. Adaptado de Rezende e Prati (2005, p. 180).

A Figura 7 representa o modelo de inferência de Mamdani no qual recebe valores na forma escalar, por meio de uma interface de entrada, Crisp, como entrada, e os converte em valores fuzzy. A máquina de inferência é responsável por processar as regras existentes no banco de regras gerando, assim, um conjunto de saída fuzzy a partir da composição de todas as regras disparadas. Por uma regra disparada entende-se: regra cujo processamento do antecedente para as entradas atuais gerou graus de pertinência não-nulos, ou seja, a relação fuzzy entre as entradas e os termos primários do antecedente é maior que zero.

A regra semântica utilizada para o processamento de inferências com 0 modelo de Mamdani é chamada de inferência de Máx-Min, por utilizar as operações de união e intersecção entre conjuntos da mesma forma que Zadeh, por meio de operadores de máximo e mínimo, respectivamente.

$$
\text { if } \mathrm{x}_{1}=\mathrm{A}_{\mathrm{i}} \text { and } \mathrm{x}_{2}=\mathrm{A}_{\mathrm{j}} \text { and } \ldots \text { and } \mathrm{x}_{\mathrm{p}}=\mathrm{A}_{\mathrm{j}} \text { then } \mathrm{y}_{1}=\mathrm{B}_{\mathrm{i}} \text { and } \mathrm{y}_{2}=\mathrm{B}_{\mathrm{m}}
$$

A representação 5, acima, x1 são as entradas do sistema, Ai .... Aj, são os termos primários definidos nas partições fuzzy de cada variável de entrada, y1 e y2 são variáveis de saída e Bi, ... Bm são termos primários definidos em suas partições fuzzy.

O processamento dos antecedentes de cada regra, que ocorre durante a conversão Escalar em fuzzy, é realizado com a interseção entre os graus de pertinência das entradas atuais nos termos primários definidos em cada uma.

Um grau de pertinência de disparo é gerado para cada regra de produção. Em que a k-ésima regra da base de conhecimento é gerada e um coeficiente de 
disparo $\mathrm{D}(\mathrm{k})$, conforme apresetando em 6, é calculado e os índices k denotam nos conjuntos fuzzy os termos primários que compõem a regra $k$ na base de conhecimentos, ou banco de regras.

Este processamento, segundo Rezende e Prati (2005, p. 181), "[..] transforma informações quantitativas em qualitativas, é considerado um processo de generalização", em inglês é comumente chamado de Fuzzification.

$$
D^{k k]}=T\left[\mu A_{1}^{k}\left(x_{1}\right\}_{\mu} \mu A_{2}^{k}\left(x_{2}\right)_{n}, \ldots, \mu A_{p}^{k}\left(x_{p}\right)\right]=\min \left[\mu A_{1}^{k}\left(x_{1}\right), \mu A_{2}^{k}\left(x_{2}\right), \ldots, \mu A_{p}^{k}\left(x_{p}\right)\right]
$$

Todas as regras as quais o coeficiente de disparo for maior que zero são ditas regras que dispararam para as entradas atuais, representando, assim, que vão contribuir para o cálculo das saídas correspondentes do sistema.

Os coeficientes de disparo limitarão os valores máximos dos conjuntos fuzzy de saída gerados por estas regras. Por fim, uma operação global de união vai compor um conjunto fuzzy para cada variável de saída, contendo todas as informações sobre todas as regras disparadas.

$$
\mu B_{i}^{l}=S_{k=1 . \ldots n}\left[T\left(D^{(k)}{ }_{s} \mu_{F_{2}},(y)\right)\right]=\max _{k=1 \ldots n}\left[\min \left(D^{k}{ }_{s} \mu_{k},(y)\right)\right], \forall y \in U_{\gamma_{k}}
$$

O processo descrito em (4), também transforma uma informação quantitativa em informação qualitativa, por meio de uma conversão. O conjunto fuzzy é gerado durante o processo de inferência pode ser utilizado diretamente em um diagnóstico qualitativo de tomada de decisão ou será convertido em um valor escalar que poderá ser utilizado por sistemas de controle. É apresentada, também, a composição do conjunto fuzzy para o caso da saída $y_{2}$ da regra evidenciada em (4). O universo de discurso desta variável de saída é composto pelos elementos $y \in U_{y 2}$.

A conversão fuzzy em Escalar transforma as informações qualitativas em uma informação quantitativa, sendo um processo de especificação. Em inglês, este processo é comumente conhecido como defuzzification.

Os métodos de centro de massa e média dos máximos são os métodos mais conhecidos de conversão fuzzy em Escalar. No qual o primeiro método calcula, para um dado conjunto fuzzy de saída, a abscissa do ponto de centro de massa correspondente e a utiliza como valor escalar de saída. O segundo método, o valor numérico da saída corresponde ao ponto do universo de discurso que equivale à 
média dos pontos máximos locais da função de pertinência do conjunto de saída, produzidos pelo processo de inferência, ambos especificadas por (5) e (6), respectivamente.

$$
\begin{aligned}
& \hat{y}_{2}=\frac{\sum_{9 \in v_{y^{2}}} y \cdot \mu_{S_{1}(y)}}{n_{9}}
\end{aligned}
$$

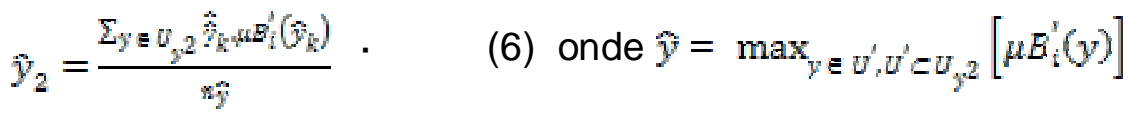

No caso do método da média dos máximos, o valor numérico da saída referente ao ponto do universo de discurso que corresponde à média dos pontos de máximo locais da função de pertinência do conjunto de saída, produzida pelo processo de inferência

\subsubsection{Modelo de Inferência de Takagi-Sugeno-Kano}

O método de inferência fuzzy proposto por Takagi e Sugeno em 1995 e Sugeno e Kano em 1988 denominado Sistema de Inferência fuzzy de Sugeno é similar ao método proposto por Mamdani em 1974. As similaridades entre os modelos de Takagi-Sugeno-Kano e Mamdani são: os métodos de inferência das entradas (fuzzification) e na aplicação dos operadores fuzzy. A principal diferença entre ambos os modelos está na função membro, ou de pertinência, de saída.

Á análise feita por Ying et al (1999, p. 513) identifica o modelo de TakagiSugeno-Kano como sendo mais econômico que o modelo de Mamdani tendo em vista que o de Takagi-Sugeno-Kano pode ter mais de um extremo em uma célula e que as funções membro não são muito limitadas às formas trapezoidal ou triangular.

\subsection{Redes Neurais Artificiais (RNA)}

O método de aprendizagem por Redes Neurais Artificiais (RNAs) conceituada por Mitchel (1997, p.81) proporciona uma abordagem robusta e objetiva a aproximação de valores reais, discretos e funções vetoriais. 
Para determinados tipos de problemas, tais como aprender a interpretar dados complexos do mundo real, as redes neurais artificiais estão entre os métodos mais eficazes de aprendizagem conhecidas atualmente. (CARVALHO, 2010)

Argarwal (2004, p.4) define que as RNAs representam um paradigma de processamento da informação inspirada na forma do sistema biológico, como o cérebro.

Pode-se inferir, então, que as RNAs são "[..] modelos matemáticos que representam estruturas neurais biológicas e que possuem capacidade computacional por meio de aprendizado e generalização" (Braga et al, 2005, p.142).

McCulloch e Pitts propuseram em 1943 o primeiro modelo de neurônio simplificado. Este modelo baseava-se nas ondas do potencial de membranas interpretando, assim, o funcionamento do neurônio na forma de um circuito binário. A Figura 8 representa o modelo de McCulloch e Pitt.

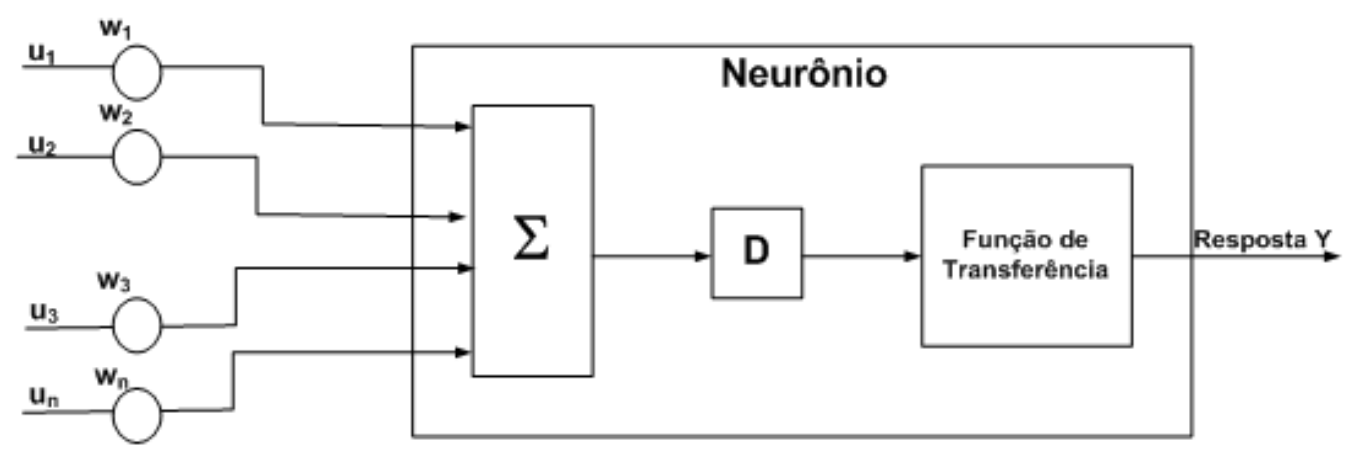

Figura 8 - Modelo de McCulloch e Pitt Adaptado de Barreto (2002, p. 14).

As entradas denotadas por $u_{i} w_{i}$ do neurônio são valores binários e são combinadas por uma somatória ponderada produzindo assim, a entrada efetiva do neurônio ou estado de ativação.

$$
\partial_{i}=\sum_{1}^{n} w_{i} u_{i}
$$


A regra de aprendizado conexionista (entrar com valores de conexões sinápticas), denominada algoritmo de aprendizado e é representado na Lei de Hebb. A Lei de Hebb é caracterizada pela propriedade de localidade. Significa que para alterar o valor de uma conexão sináptica deve obedecer a uma relação lógica necessária para que sejam produzidos os efeitos ao algoritmo (plausibilidade biológica) conforme a seguir:

$$
\Delta w_{i j}=\eta x_{i} o_{j}
$$

Nos quais:

$\underline{\mathbf{w}}_{\mathrm{i}}$ intensidade de conexão entre os neurônios;

$\underline{\Delta \mathbf{w}_{\mathrm{ij}}}$ : acréscimo da intensidade de conexão entre os neurônios i e j;

n: parâmetro que define a intensidade da correção chamada taxa de aprendizado;

$\underline{\mathbf{x}}_{\mathrm{i}}$ : estado de ativação do neurônio i;

ọ: saída do neurônio j.

A expressão referente a Lei de Hebb consta em 8 e encontra-se em um estado muito simplificado. A Regra Delta é uma versão mais sofisticada da Lei de Hebb e considera os seguintes aspectos:

- O valor da modificação da intensidade da conexão sináptica para as mesmas excitações dos neurônios envolvidos pode variar conforme o tempo;

- A modificação da intensidade da conexão sináptica $\underline{\Delta w_{i j}}$ de $\underline{w}_{i j}$ pode resultar em um efeito não linear;

- A modificação da intensidade da conexão sináptica depende dos neurônios vizinhos.

A regra delta pode ser considerada biologicamente aplicável tendo em vista que utiliza apenas as informações locais à sinapse para gerar o aprendizado.

A Lei de Hebb pode ser, por outro lado, interpretada como um modelo matemático de um mecanismo de seleção. 


\subsection{Aprendizado de Conjunto de Regras}

Para Monard e Baranauskas (2005, p. 90-91) o aprendizado de máquina "é uma área da inteligência artificial cujo objetivo é o desenvolvimento de técnicas computacionais sobre o aprendizado bem como a construção de sistemas capazes de adquirir conhecimento de forma automática". Um sistema de aprendizado é um programa de computador que toma decisões baseado em experiências acumuladas por meio de soluções bem-sucedidas de problemas anteriores.

Em linhas gerais, o aprendizado de máquina pode ser caracterizado por uma série de práticas voltadas para a solução de problemas para os quais geralmente não se conhece a priori uma solução ou modelagem capaz de resolvê-lo.

O aprendizado pode ser classificado como indutivo no qual pode ser entendido como :

[..] a forma de inferência lógica que permite obter conclusões genéricas sobre um conjunto particular de exemplos. Ela é caracterizada pelo raciocínio originado em um conceito especifico e generalizado, ou seja, da parte para o todo (MONARD e BARANAUSKAS, 2005, p. 90).

Neste contexto, classifica-se o conhecimento indutivo em dois grandes grupos conforme descritos abaixo:

- Aprendizado supervisionado: o algoritmo indutor recebe um conjunto de exemplos de treinamentos para os quais o rótulo da classe associada é conhecido;

- Aprendizado não-supervisionado: o algoritmo indutor analisa 0 conjunto de exemplo fornecido e tenta determinar o agrupamento alguns deles de alguma maneira.

Este trabalho não objetiva detalhar com maior profundidade o aprendizado não-supervisionado.

A Tabela 10 elenca os principais conceitos relacionados ao aprendizado supervisionado: 
Tabela 10 - Principais Conceitos relacionados com Aprendizado Supervisionado adaptado de Monard e Baranauskas (2005, pp. 95-98).

\begin{tabular}{ll}
\hline \multicolumn{1}{c}{ Conceito } & \multicolumn{1}{c}{ Descrição } \\
\hline Atributo & Descreve uma característica ou aspecto de um exemplo. \\
\hline Classe & $\begin{array}{l}\text { Todo exemplo possui um atributo especial denominado } \\
\text { rótulo ou classe. }\end{array}$ \\
\hline $\begin{array}{l}\text { Classificador } \\
\text { ou hipótese }\end{array}$ & $\begin{array}{l}\text { Dado um conjunto de exemplos de treinamento. Um } \\
\text { indutor gera como saída um classificador. }\end{array}$ \\
\hline Bias & É qualquer preferência de uma hipótese sobre outra, além \\
& da simples consistência com os exemplos. \\
\hline Regra & Assume a forma If $\mathrm{L}$ Then $\mathrm{M}$ ou na forma simbólica $\mathrm{L} \rightarrow \mathrm{M}$, \\
& no qual $\mathrm{L}$ representa condição ou premiça e $\mathrm{M}$ a \\
& conclusão. \\
\hline
\end{tabular}

Um outro método de aprendizado é denominado Aprendizado de conjunto de regras, ou learn sets of rules, e é caracterizado pelo processo de se encontrar, por meio de um conjunto de exemplos de treinamento, um conjunto de regras que pode ser utilizada para a classificação ou predileção. Uma regra de classificação pode ser representada na forma se <condição $=>$ classe $>$. Condição representa o conjunto de condições para classificar o problema.

Uma das principais características do aprendizado de regras é o algoritmo de cobertura seqüencial (Sequential Covering Algorithms). O funcionamento de algoritmo de cobertura seqüencial está intimamente ligado ao seu sub-algoritmo denominado aprenda uma regra (learning-one-rule) o qual aceita exemplos de treinamento tanto positivos quanto negativos.

A Figura 9 mostra o algoritmo de cobertura seqüencial. 
SEQUETIAL-COVERING (Target Attribute, Attributes, Examples,

Threshold)

Learned_rules $=\{\}$

Rule $=$ LEARN-ONE-RULE(Target Attribute, Attributes, Examples)

WHILE PERFORMANCE (Rule, Examples) > Threshold DO

Learned_rules $=$ Learned_rules + Rules

Examples $=$ Examples - \{examples correctly classified by rule $\}$

Rule $=$ LEARN-ONE-RULE(Target Attribute, Attributes, Examples)

Learned_rules $=$ sort Learned_rules accord to PERFORMANCE over

examples

return Learned_rules

Figura 9 - Algoritmo de Cobertura Seqüencial.

Adaptado de Mitchel (1997, p. 276).

\subsection{Considerações Parciais}

Este capítulo objetivou a conceituação dos principais métodos envolvidos em inteligência computacional. O uso, ou não, de um método aqui apresentado está condicionado às experimentações e simulações constantes no capítulo 5 deste trabalho. 


\section{O GERADOR AUTOMÁTICO DE CASOS DE TESTES}

Este capítulo detalha o modelo arquitetônico da ferramenta proposta, Automatic Test Software Interface - ATSI. Visando descrever suas diversas fases e componentes como também as interações existentes com os componentes externos ou atores.

\subsection{Modelo conceitual do gerador automático de casos de teste}

O modelo conceitual do gerador automático de casos de testes funcionais é mostrado na Figura 10, e é composto por uma interface que possibilita ao engenheiro de testes configurar os testes a serem executados e definir qual técnica de testes a ser aplicada para um dado teste. Possibilita, também, a montagem da base de exemplos ou utilizar uma já existente, isto pode variar conforme o objeto do teste.

O modelo conceitual possui uma base de conhecimentos local destinado ao armazenamento dos exemplos implementados ou gerados, os parâmetros de configurações para o ATSI como também os novos casos de testes gerados e posteriormente classificados.

O processo de geração de casos de testes tem a finalidade buscar os dados armazenados na base de conhecimento, e gerar novos casos de testes utilizando algoritmos de cobertura seqüencial. Depois de gerados, os casos de testes são armazenados e o módulo testador é incumbido de enviar os valores de entrada, oriundos dos casos de testes ora gerados, e receber os valores de retornos obtidos do software testado. 


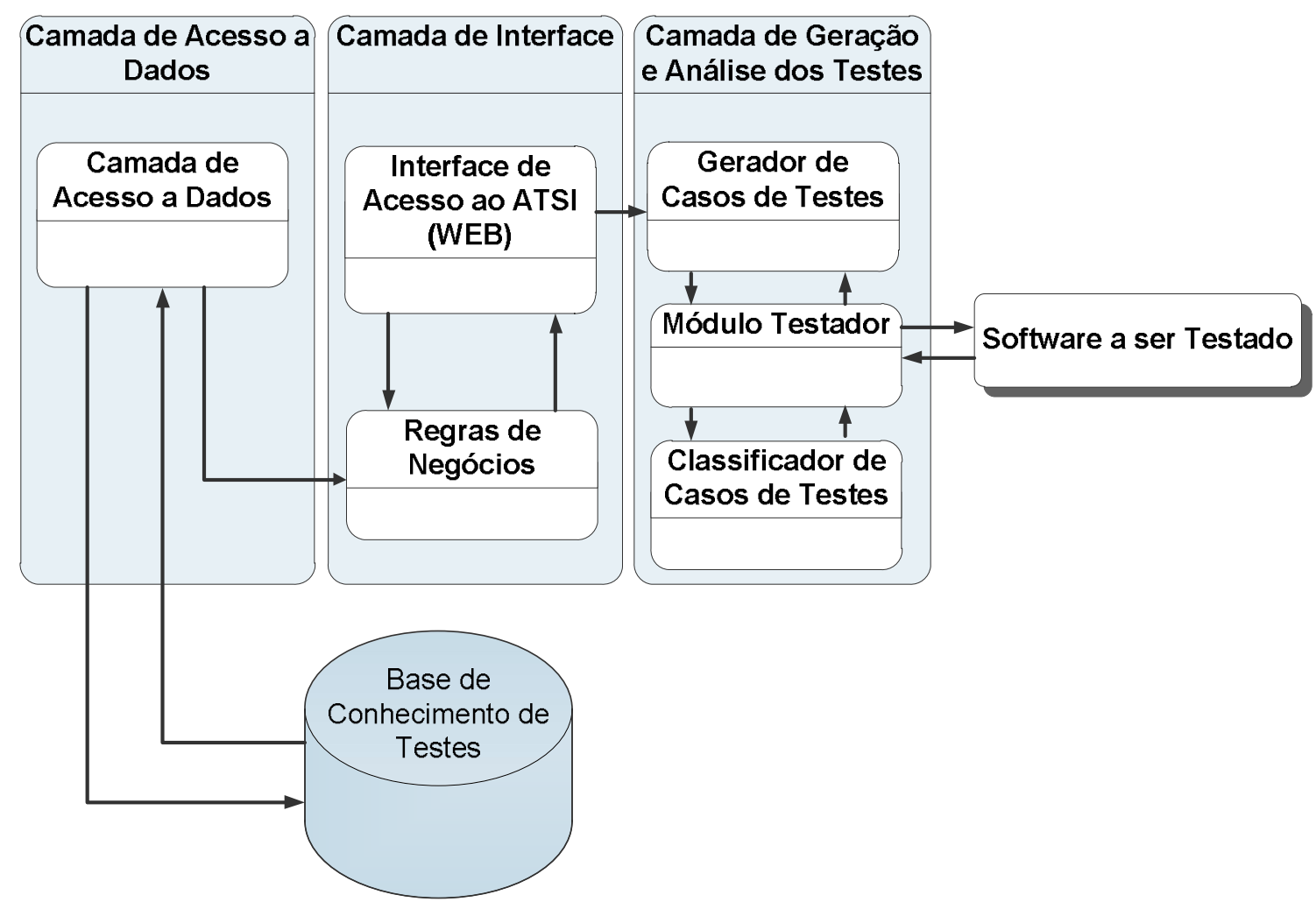

Figura 10 - Modelo arquitetônico do ATSI.

Fonte: Autor

Os resultados obtidos com o módulo testador são armazenados e posteriormente utilizados pelo classificador de casos de testes. Após o armazenamento dos dados obtidos com a execução dos novos casos de testes, estes passarão por um processo de classificação em que um caso de teste pode compor uma base de exemplo se for classificado como "Aderente" ou "Pouco Aderente".

\subsection{A base de Conhecimentos}

A base de conhecimento representada na Figura 11 é responsável pelo armazenamento dos dados referentes às entidades de configurações do ATSI, da base de treinamento e dos casos de testes gerados e classificados. 


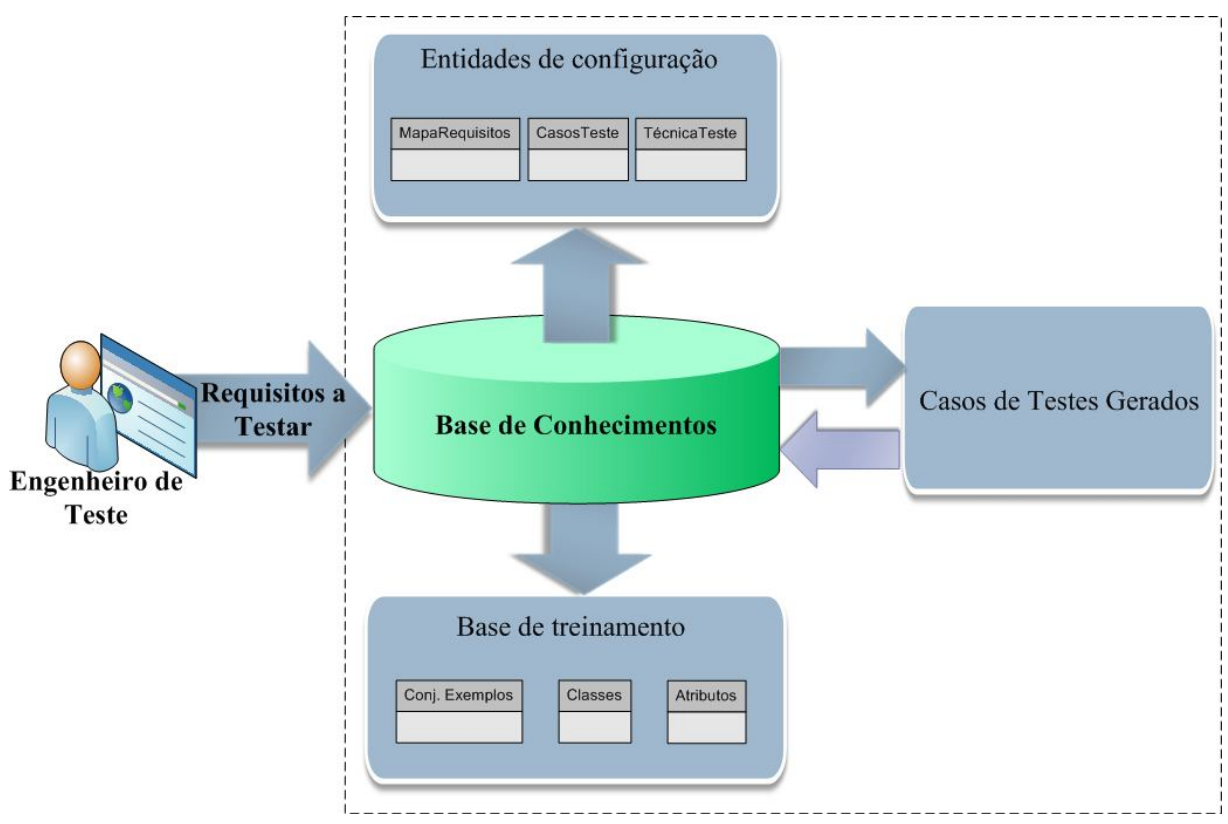

Figura 11 - Representação da Base de Conhecimentos

Fonte: Autor

As entidades de configuração do ATSI armazenarão os dados pertinentes ao mapa de requisitos, aos casos de testes propriamente ditos e a técnica de teste a ser aplicada na execução do teste.

O mapa de requisitos, ou Documento de Requisitos, conterá os dados referentes aos requisitos do software como dados de entrada, forma de processamento e valores esperados como saída.

O caso de teste possuirá um relacionamento forte com a entidade de mapa de requisitos tendo em vista a dependência entre ambas. A entidade caso de teste será responsável por armazenar os dados referentes ao nome do caso de teste, aos tipos utilizados nos argumentos de entrada e retorno, valores obtidos e situação do teste após a execução.

A entidade de técnica de teste é responsável pelo armazenamento dos dados referentes ao tipo de técnica que será utilizada na execução de um dado teste como, por exemplo, grafo causa efeito. 


\subsection{Gerador de Casos de Testes}

O gerador de casos de testes é composto por três partes distintas: um extrator de dados da base de conhecimento, um classificador de exemplos e um algoritmo de cobertura.

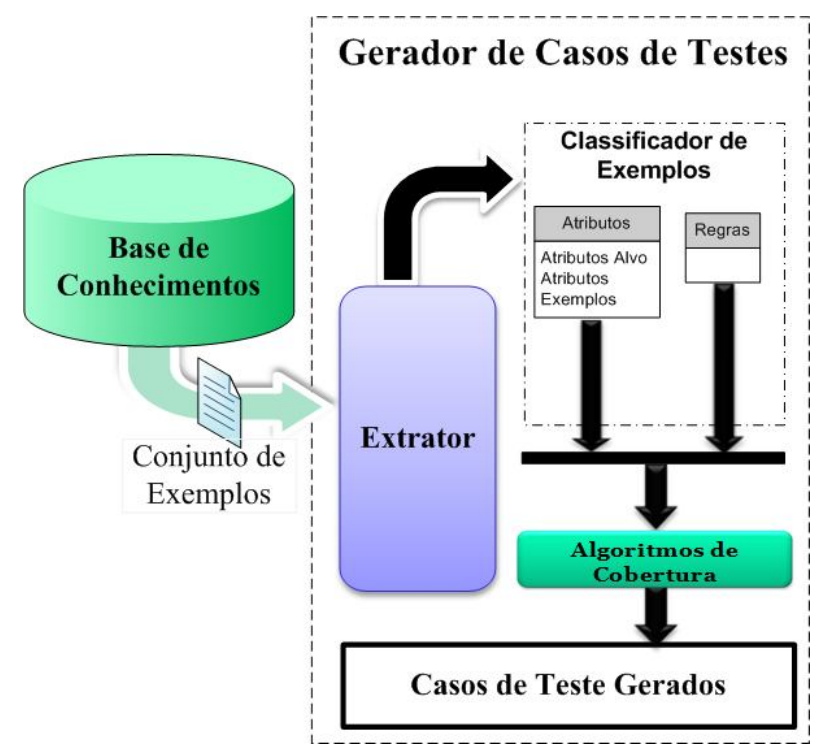

Figura 12 - Representação do Gerador de Casos de Testes Fonte: Autor

O módulo extrator é responsável por buscar na base conhecimentos os dados referentes à configuração dos testes e o conjunto de exemplos para iniciar o ciclo de geração de testes.

O processo de classificação dos exemplos é responsável por recepcionar os dados trazidos pelo módulo extrator e dispô-los em uma árvore de decisão, separando os atributos, as regras e as classes.

O método utilizado pelo gerador de casos de testes automáticos é baseado na técnica de aprendizado de conjunto de regras, algoritmos de cobertura seqüencial. Outros métodos como Info-fuzzy network (IFN), conforme Last, Friedman e Kandel (2003), também são utilizados com a finalidade de gerar massas de testes automaticamente. Entretanto a aplicação dos algoritmos de cobertura seqüencial para geração automática de casos de testes podem ser mais eficazes face aos algoritmos IFN devido a uma menor complexidade computacional. 
Aprendizado de máquina (Machine Learning) é uma técnica computacional que fornece argumentos ao computador para que este simule o comportamento humano e que segundo Rezende e Prati (2005, p. 89) "[..] servem para a construção de sistemas capazes de adquirir conhecimento automaticamente". O aprendizado de um conjunto de regras é uma das técnicas comuns de aprendizado de máquina.

O gerador de casos de testes, mostrado na Figura 12, é composto por três partes distintas: um extrator de dados da base de conhecimento, um classificador de exemplos e um algoritmo de cobertura.

O extrator é responsável por buscar na base conhecimentos os dados referentes à configuração dos testes e o conjunto de exemplos para iniciar o ciclo de geração de testes.

O processo de classificação dos exemplos é responsável por recepcionar os dados trazidos pelo extrator e dispô-los em uma árvore de decisão, separando os atributos, as regras e as classes.

\subsection{Módulo Testador}

O módulo testador tem a missão de executar e coletar os resultados ora aplicados ao software em teste. Estes resultados coletados serão armazenados na base de conhecimento objetivando seu uso no módulo de classificação dos testes gerados e executados.

A Figura 13 mostra o processo de execução dos casos de testes por meio do módulo testador.

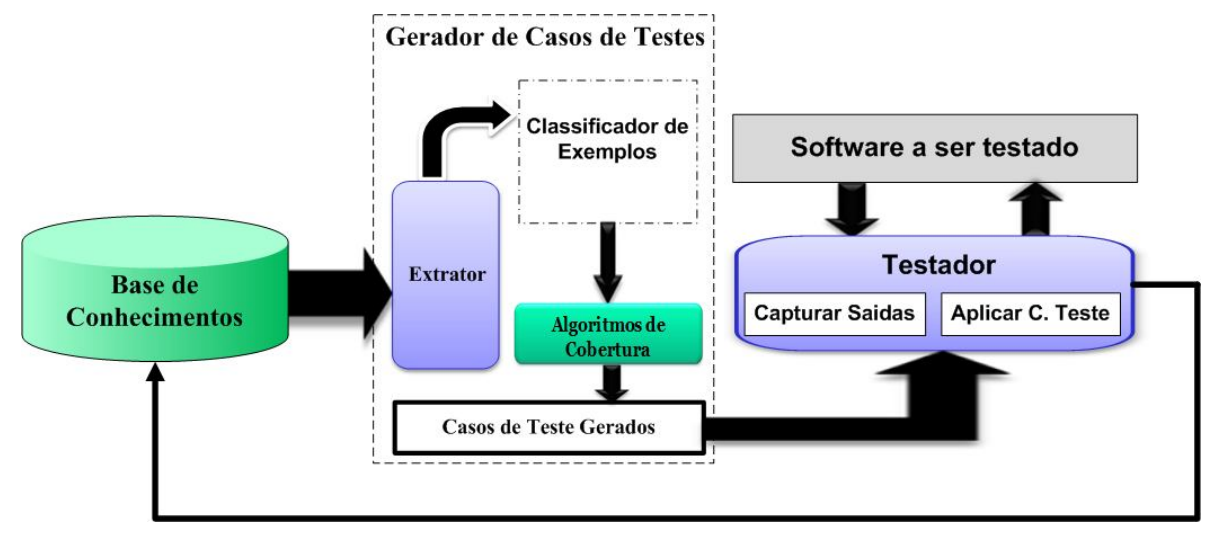

Figura 13 - Representação do Módulo Testador

Fonte: Autor 


\subsection{O Classificador de Casos de Teste}

A utilização da lógica fuzzy para análise de sistemas complexos e de processo de tomada de decisão encontra embasamento na abordagem esboçada por Zadeh que se fundamentou na premiça de que "os elementos chaves do pensamento humano não são apenas números, mas rótulos de conjuntos fuzzy" (ZADEH, p.28, 1973). No contexto da utilização em processos de tomada de decisão ou mesmo em sistemas de apoio à decisão e considerando ainda que a lógica fuzzy não esteja restrita apenas aos sistemas de controle pode-se, por tanto, utilizá-la para classificar os resultados dos testes gerados.

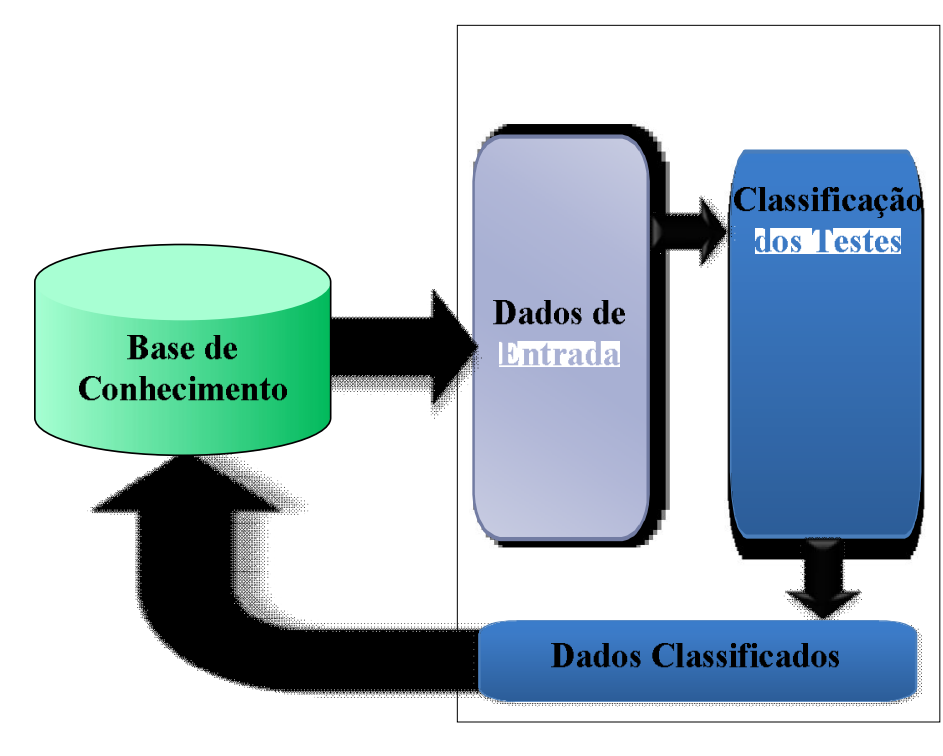

Figura 14 - Representação do Classificador de Casos de Testes.

Fonte: Autor

O processo de classificação dos resultados dos testes poderá ser composto por uma máquina de inferência fuzzy ou uma rede neural artificial e está representado na Figura 14. Este processo é composto por um conjunto de entrada, que são os valores produzidos pelos testes. 


\subsection{Considerações Arquiteturais}

O modelo arquitetônico do ATSI é composta por três camadas distintas, conforme a Figura 10: Acesso a Dados, Interface e a Geração e Análise dos Testes. A camada de acesso a dados é responsável pelas operações relacionadas á persistência com o banco de dados.

A camada de Interface é responsável pelas regras de negócios que envolvem os testes em questão e pela interface com o usuário deste sistema. As regras de negócios podem ser entendidas como o conjunto de todo e qualquer elemento que caracterize o software a ser testado, tais quais: valores de retornos esperados; regras ou condições de testes constantes nos requisitos e valores de entradas. $A$ interface do ATSI é responsável pela comunicação com o engenheiro de testes e tem seus principais componentes representados na Diagrama 1.

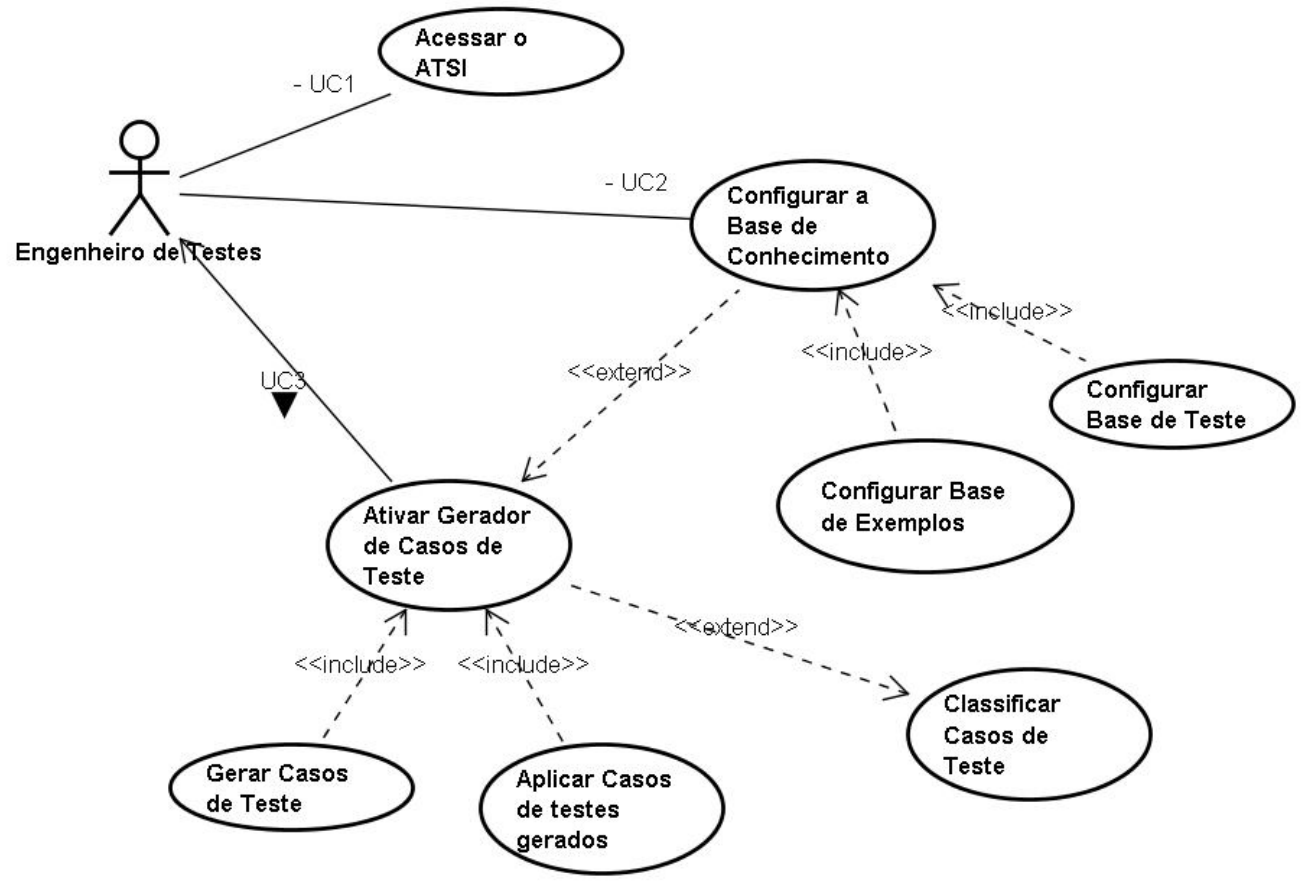

Diagrama 1 - Diagrama de Casos de Uso do ATSI.

Fonte: Autor

A camada de Geração e Análise dos Testes representa o centro nevrálgico do ATSI propriamente dita e é composta pelo gerador de casos de testes, pelo módulo testador e pelo classificador de casos de testes. 
O gerador de casos de testes é responsável por analisar a base de conhecimento referente ao software a ser testado, criada pelo engenheiro de testes, e gerar novos casos de testes a partir dos casos de testes aqui denominados como casos de testes primários ou base treinamento. A base de treinamento contém também as entidades de configurações dos testes tais quais: a técnica de testes de software funcional a ser empregada e o mapa de requisitos propriamente dito.

O módulo testador tem a missão de buscar os casos de testes ora gerados e os executa armazenando os valores de retorno na base de conhecimento referentes ao software em testes.

O classificador de casos de testes objetiva interpretar os resultados obtidos com os confrontando-os com os resultados esperados. Os resultados da classificação dos valores de saída dos testes efetuados serão representados na forma lingüística, como já exibido na Figura 14 e apresentados por meio da interface do ATSI para o engenheiro de testes.

\subsection{Considerações Parciais}

Este capítulo objetivou detalhar as principais características relacionadas à ferramenta ATSI no que diz respeito à sua arquitetura e ao processo de gerar os casos de testes automaticamente, executá-los e por fim classificá-los.

Os principais objetivos da geração automática de casos de testes funcionais podem ser entendidos como a possibilidade de reutilização e melhor alcance nos resultados produzidos pelos casos de testes gerados. 


\section{PROVA DE CONCEITO}

Este capítulo evidencia a comparação entre dois métodos de inteligência computacional apresentadas no capítulo 3. Dentre os quais a lógica fuzzy e redes neurais artificiais (RNAs) tendo em vista que ambos os métodos podem ser utilizados tanto para gerar os casos de testes como para classificá-los.

No contexto destes dois métodos estudados e fundamentados por Jin et al (2008, pp.727-730) e Last, Friedman e Kandel (2003, pp. 388-396) ambos os trabalhos abordam a geração automática de casos de testes. Sendo que o primeiro trabalho utiliza o método de RNAs para gerar os casos de testes e o segundo utiliza o método fuzzy, mais precisamente info-fuzzy network - IFN.

Com o intuito de fundamentar a escolha de um ou outro método abordado neste trabalho e objetivando a sua aplicação na ferramenta proposta, ATSI, e considerando também a comparação entre estes dois métodos feita por Cios, Sala e Berke (1996, p. 1) os quais analisam as potencialidades entre as RNAs e a lógica fuzzy ressaltando que em seus experimentos foram adotados para os conjuntos de treinamentos composto de duzentos e cinqüenta entre entradas e saídas para cada exemplo.

Esta análise considerou os modelos Linear FeedForward Network (LFN), Multi-layer Network com unidades sigmoidal e Radial Basis Function (RBF) todas concernentes ao método de RNAs e Mamdani e Takagi-Tsugeno relativos a fuzzy.

Com base nos resultados apresentados os autores concluíram que no contexto da modelagem de processos, que mapeiam as entradas e saídas, que ambos os métodos tanto RNAs quanto fuzzy mostraram-se eficazes. Entretanto, afirmaram que "o conhecimento embutido em um sistema de lógica fuzzy pode ser expressa na forma IF ... THEN, nos quais as suas regras podem ser modificada pelo especicalista".

Considerando este cenário elaborou-se uma simulação utilizando o framework AFORGENET (2010) desenvolvida em C\#. Este framework disponibiliza bibliotecas contendo os principais métodos de inteligência computacional, dentre os quais: RNAs, fuzzy, Algoritmos Genéticos e aprendizado de máquina.

Para a análise dos resultados utilizou-se a ferramenta Metric Code do ambiente integrado de desenvolvimento de software Microsoft Visual Studio 2008. 
Considerou-se, também, as métricas de Complexidade Ciclomática ${ }^{4}$, Número de Linhas de Código (LC) e uma pequena função escrita em C\# para retornar o tempo de execução gasto por cada método.

\subsection{Simulações}

A necessidade de se definir um método para gerar e outro para classificar os casos de testes motivou a geração de dois tipos simulações, na primeira simulação procurou-se simular a execução de ambos os métodos (fuzzy e RNA) para a obtenção de métricas de execução e consumo de recurso e assim ter-se um possível método a ser utilizado na classificação dos testes. A segunda simulação é a prova de conceito do ATSI propriamente dita utilizando o método de aprendizado de regras para gerar os casos de testes e um método para classificá-los.

A análise das simulações adotou o método comparativo para em primeiro lugar evidenciar as similaridades entre os processos de inferência fuzzy e RNAs. Ressalta-se que a principal similaridade é que ambos os métodos baseiam-se em elementos de processamento em redes para inferir os dados de entrada. Em segundo lugar implementaram-se dois algoritmos em C\# visando executar, por um lado, todas as fases de uma máquina de inferência fuzzy e por outro lado todas as fases de uma RNA.

O principal objetivo destas simulações é gerar uma comparação entre os algoritmos, implementados, de RNAs e fuzzy com o intuito de verificar qual destes pode ser melhor aplicado, ou não, na ferramenta ATSI proposta no que tange a classificação dos testes gerados. Neste contexto, buscou-se desenvolver uma função em C\# capaz de herdar os métodos do Framework AForge para ambos os métodos (fuzzy e RNAs). Nestas funções foram inseridos marcos de controle de tempo com a finalidade de expressar o tempo gasto por cada função executada. Estas funções utilizam os conceitos elementares de cada método para executar suas principais características.

Para fuzzy foi considerado um software hipotético que tem como finalidade analisar o desempenho de um computador considerando que os principais fatores

\footnotetext{
${ }^{4}$ Complexidade Ciclomática é uma métrica desenvolvida por Thomas J. McCabe e reflete diretamente o número de caminhos independentes que um programa pode tomar durante a sua execução.
} 
que impactam diretamente no consumo de seus recursos são a memória e o tempo de resposta. A Tabela 11 mostra a modelagem fuzzy desta problemática.

Tabela 11 - Modelagem fuzzy para desempenho de computadores.

\begin{tabular}{lll}
\hline \multicolumn{1}{c}{ Valores Crisp (U) } & Variáveis Lingüísticas & Variáveis Fuzzy \\
& & \\
\hline 10, 50, 60 e 90 & Memória & $\mathrm{NO}=$ Normal \\
& (Entrada) & $\mathrm{MO}=$ Meio Ocupada \\
& & $\mathrm{OC}=$ Ocupada \\
\hline 1seg, 5seg e 11seg & Tempo de Resposta & $\mathrm{RP}=$ Rápido \\
& (Entrada) & $\mathrm{TL}=$ Lento \\
& & $\mathrm{ML}=$ Muito Lento \\
\hline & Desempenho & $\mathrm{DB}=$ Bom \\
& (Saída) & $\mathrm{DR}=$ Aceitável \\
& & $\mathrm{RR}=$ Ruim \\
\hline
\end{tabular}

Fonte: Autor

Os valores Crisps para a variável lingüística de entrada Memória estão expressos em percentual e representa o estado do consumo atual do recurso, no caso a Memória. As variáveis fuzzy de entrada estão representadas por Normal (NO), Meio Ocupada (MO) e Ocupada (OC).

Os valores Crisps para a variável lingüística Tempo de Resposta, que representa o tempo gasto por um computador para retornar um valor após a realização de uma operação, estão expressas em segundos. As variáveis fuzzy associadas a esta variável lingüística são: Rápida (RP), Lenta (LT) e Muito Lenta $(\mathrm{ML})$.

As regras geradas para esta análise estão dispostas na Tabela 12. 
Tabela 12 - Regras de inferência fuzzy.

\begin{tabular}{cl}
\hline $\begin{array}{c}\text { Número } \\
\text { da Regra }\end{array}$ & \multicolumn{1}{c}{ Regras } \\
\hline $\mathbf{1}$ & $\begin{array}{l}\text { IF Memoria IS Normal AND TempodeResposta IS Rapida THEN } \\
\text { Desempenho IS Bom }\end{array}$ \\
\hline $\mathbf{2}$ & $\begin{array}{l}\text { IF Memoria IS Normal AND TempodeResposta IS Lenta THEN } \\
\text { Desempenho IS Aceitavel }\end{array}$ \\
\hline $\mathbf{3}$ & $\begin{array}{l}\text { IF Memoria IS Normal AND TempodeResposta IS MuitoLenta THEN } \\
\text { Desempenho IS Ruim }\end{array}$ \\
\hline $\mathbf{4}$ & $\begin{array}{l}\text { IF Memoria IS MeioOcupada AND TempodeResposta IS Rapida } \\
\text { THEN Desempenho IS Bom }\end{array}$ \\
\hline $\mathbf{6}$ & $\begin{array}{l}\text { IF Memoria IS MeioOcupada AND TempodeResposta IS Lenta THEN } \\
\text { Desempenho IS Aceitavel }\end{array}$ \\
\hline $\mathbf{7}$ & IF Memoria IS MeioOcupada AND TempodeResposta IS MuitoLenta \\
& IF Memoria IS Ocupada AND TempodeResposta IS Rapida THEN \\
\hline $\mathbf{8}$ & Desempenho IS Bom \\
\hline $\mathbf{9}$ & IF Memoria IS Ocupada AND TempodeResposta IS Lenta THEN \\
& IF Memoria IS Ocupada AND TempodeResposta IS MuitoLenta \\
& THEN Desempenho IS Ruim \\
\hline
\end{tabular}

Fonte: Autor

A variável lingüística de saída denominada de Desempenho está condicionado ao tempo de resposta e a memória no que tange a carga de stress ao qual foi submetida. A proporcionalidade que envolve a variável Desempenho está diretamente ligada aos resultados obtidos com as variáveis de entrada (memória e tempo de execução).

Os métodos de fuzzification e defuzzification utilizados foram baseados em trapezoidal e centróide (Takagi-Sugeno), respectivamente.

Para a experimentação do método de RNAs adotou-se o mesmo padrão de cenário que o utilizado na experimentação de fuzzy para que se possa efetuar testes 
com a mesma similaridade de condições. Evidentemente, respeitaram-se as características individuais de cada método testado.

Ressalta-se que as RNAs que possuem apenas duas camadas (entrada e saída) podem ser entendidas como limitadas e normalmente são pouco utilizadas e que para esta simulação não foram utilizados parâmetros para gerar aprendizado (bias, perceptrons entre outros). Com isto, configurou-se uma RNA contendo as seguintes características:

- Três entradas (u1, u2 e u3);

- Três camadas ou níveis;

- Quatro neurônios no primeiro nível e um neurônio no segundo nível.

Graficamente a RNAs configurada pode ser representada conforme a Figura 15.

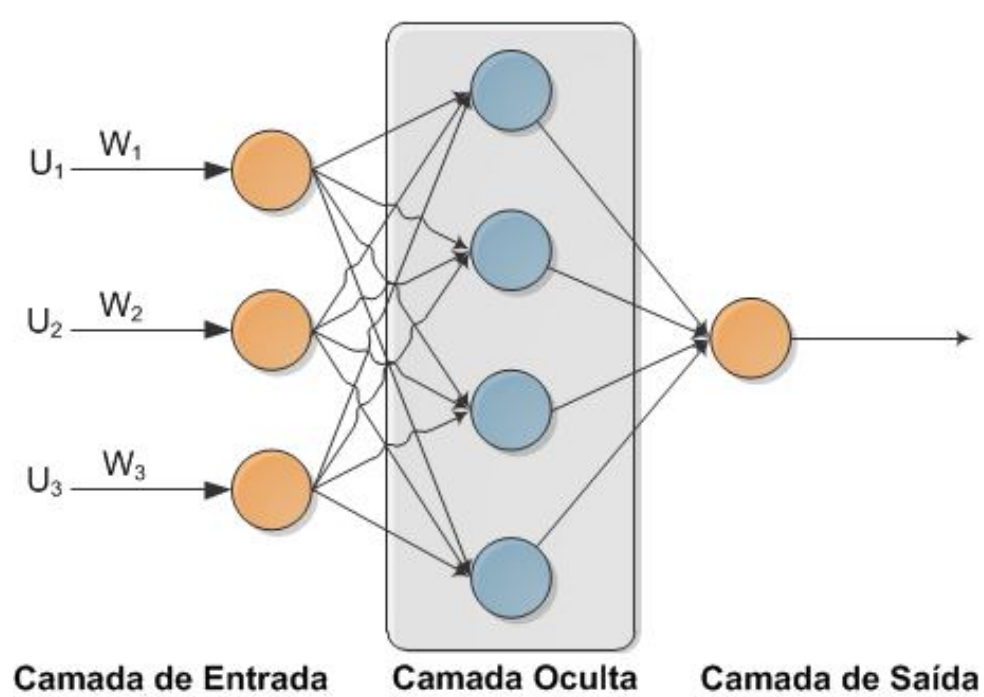

Figura 15 - Representação do Modelo de RNA.

Fonte: Autor

A Figura 15 mostra uma rede direta (feedforward) são redes cujos os grafos não possuem ciclos. As redes com ciclos são aquelas cujo grafo de conectividade possui ao menos um ciclo e são denominadas (feedback).

A primeira camada representa os neurônios que recebem excitação e é denominada de camada de entrada. A segunda camada é denominada de camada oculta. A última camada é denominada de camada de saída. 
A função de ativação utilizada é a sigmoidal devido à abordagem que ela utiliza em relação ao uso de um valor para o limite inferior e um para o limite superior para a entrada. A função sigmoidal pode ser expressa matematicamente conforme (9).

$$
\partial=\frac{1}{1+(-\theta)^{2}}
$$

Adotou-se o mesmo cenário utilizado para a simulação com o modelo fuzzy tendo em vista que ambas as simulações devem conter as mesmas características afim de gerarem resultados teoricamente semelhantes.

A Figura 16 mostra a execução do Code Metrics do MS-Visual Studio 2008. A complexidade Ciclomática é calculada conforme (10):

$$
\mathrm{CC}=\mathrm{A}-\mathrm{N}+2 \mathrm{C}
$$

Nos quais CC representa a complexidade ciclomática, A é o número de arestas do grafo, $\mathrm{N}$ é o número de nós do grafo e $\mathrm{C}$ é o número de componentes conectados. Em outras palavras sabe-se que a quantidade testes necessários para exercitar um determinado trecho de código é diretamente proporcional à sua árvore de decisão.

Os objetivos deste trabalho não visam demonstrar o cálculo da Complexidade Ciclomática, mas, sim, utilizá-la com parâmetro de comparação entre os dois modelos em estudo. Com isto, utilizou-se a ferramenta para cálculo de métricas Code Métrics que compõe o ambiente de desenvolvimento Microsoft Visual Studio. 


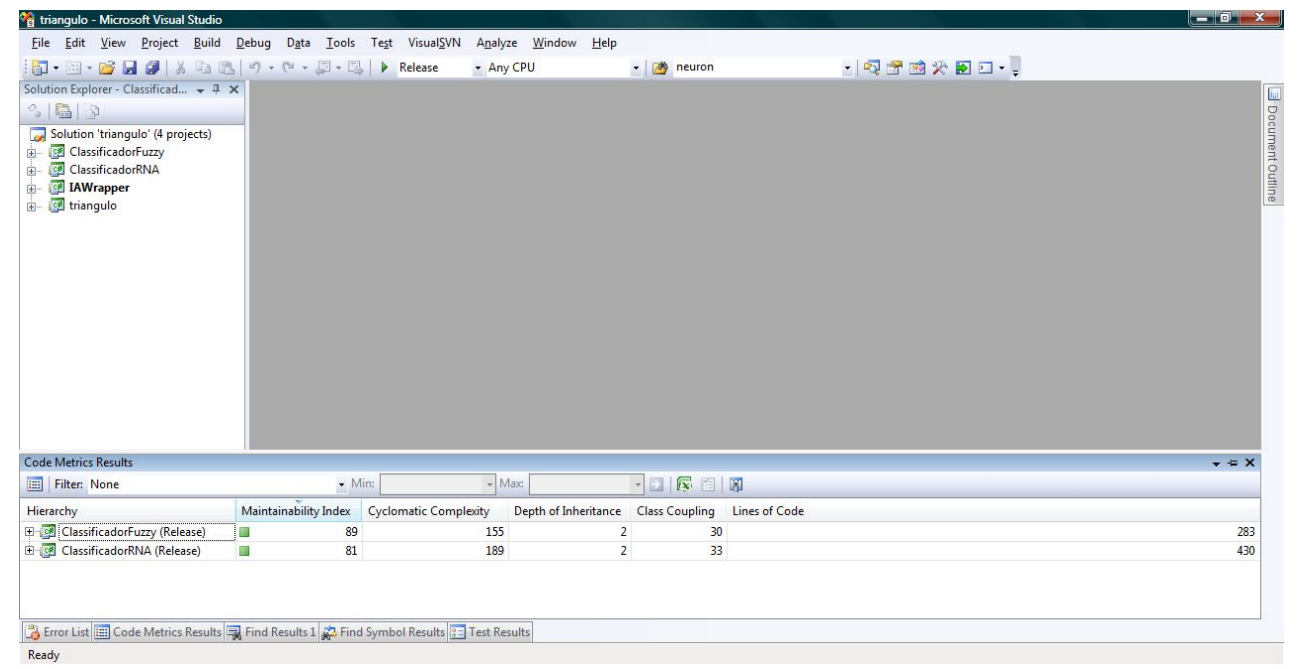

Figura 16 - Code Metrics do MS-Visual Studio 2008.

Os algoritmos utilizados para a execução dos dois métodos, Fuzzy e RNAs, estão ilustrados nas Figura 17 e Figura 18, respectivamente. 
// linguistic labels (fuzzy sets) Percentual de consumo da memória\#Input Labe\#\#

FuzzySet fsNormal = new FuzzySet("Normal", new TrapezoidalFunction(10, 39, TrapezoidalFunction.EdgeType.Right));

FuzzySet fsMeioOcupada = new FuzzySet("MeioOcupada", new TrapezoidalFunction(40, 45, 50, 59));

FuzzySet fsOcupada = new FuzzySet("Ocupada", new TrapezoidalFunction(60, 90, TrapezoidalFunction.EdgeType.Left));

// Memoria

Linguistic Variable IvMemoria = new LinguisticVariable("Memoria", 10, 90);

IvMemoria.AddLabel(fsNormal);

IvMemoria.AddLabel(fsMeioOcupada);

IvMemoria.AddLabel(fsOcupada);

// linguistic labels Tempo de Resposta

FuzzySet fsRapida = new FuzzySet("Rapida", new TrapezoidalFunction(1.0, 1.1, 1.2, 1.3));

FuzzySet fsLenta = new FuzzySet("Lenta", new TrapezoidalFunction(2, 2.5, 2.9, 3.0));

FuzzySet fsMuitoLenta = new FuzzySet("MuitoLenta", new TrapezoidalFunction(4.0, 4.5, 5.0, 10));

// Tempo de Resposta

LinguisticVariable IvTempodeResposta = new LinguisticVariable("TempodeResposta", 0, 10);

IvTempodeResposta.AddLabel(fsRapida);

IvTempodeResposta.AddLabel(fsLenta);

IvTempodeResposta.AddLabel(fsMuitoLenta);

// linguistic labels (fuzzy sets) Desempenho

FuzzySet fsBom = new FuzzySet("Bom", new TrapezoidalFunction(1.4, 1.7, 1.8, 1.9));

FuzzySet fsAceitavel = new FuzzySet("Aceitavel", new TrapezoidalFunction(2.1, 2.3, 2.6, 2.9));

FuzzySet fsRuim = new FuzzySet("Ruim", new TrapezoidalFunction(4.1, 4.3, 5.1, 10));

// Desempenho

LinguisticVariable IvDesempenho = new LinguisticVariable("Desempenho", 0, 10);

IvDesempenho.AddLabel(fsBom);

IvDesempenho.AddLabel(fsAceitavel);

IvDesempenho.AddLabel(fsRuim);

// the database

Database fuzzyDB = new Database();

fuzzyDB.AddVariable(IvMemoria);

fuzzyDB.AddVariable(IVTempodeResposta);

fuzzyDB.AddVariable(IvDesempenho);

// creating the inference system

InferenceSystem IS = new InferenceSystem(fuzzyDB, new CentroidDefuzzifier(1000));

// going straight: Rules

IS.NewRule("Rule 1" , "IF Memoria IS Normal AND TempodeResposta IS Rapida THEN Desempenho IS Bom');

IS.NewRule("Rule 2" , "IF Memoria IS Normal AND TempodeResposta IS Lenta THEN Desempenho IS Aceitavel');

IS.NewRule("Rule 3" , "IF Memoria IS Normal AND TempodeResposta IS MuitoLenta THEN Desempenho IS Ruim");

// setting inputs

IS.SetInput("Memoria", 10);

IS.Setlnput("TempodeResposta", 2.0);

// getting outputs

FuzzyOutput fuzzyOutput = IS.Executelnference("Desempenho");

Figura 17 - Algoritmo utilizado para executar o modelo Fuzzy. 


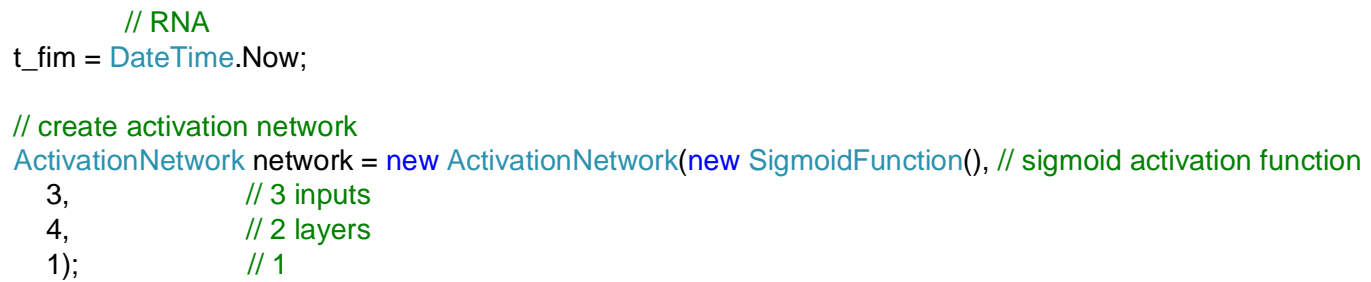

// 3 entradas para os neurônios

ActivationNeuron nNeuronio = network[0][0];

ActivationLayer aclLayer $=$ new ActivationLayer(3, 3, new SigmoidFunction());

SigmoidFunction sifFun = new SigmoidFunction(50);

sifFun.Alpha = 15;

sifFun.Function(15);

acILayer.SetActivationFunction(sifFun);

Console.WriteLine(aclLayer.NeuronsCount);

sifFun.Alpha $=50$;

sifFun.Function(50);

sifFun.Alpha $=60$;

sifFun.Function(60);

sifFun. Alpha = 100;

sifFun.Function(100);

nNeuronio.ActivationFunction.Function(1);

Console.WriteLine(nNeuronio.Threshold.ToString());

$\mathrm{t}$ fim = DateTime.Now;

$\mathrm{t}$ diferenca $=\mathrm{t}$ fim.Subtract( $\mathrm{t}$ inicio);

Console.WriteLine("O tempo gasto pela função RNAs foi $\{0\}$ ", t_diferenca.TotalSeconds.ToString())

Figura 18 - Algoritmo utilizado para executar o modelo RNA.

A Figura 19 mostra o retorno produzido pela execução dos algoritmos dos dois modelos.

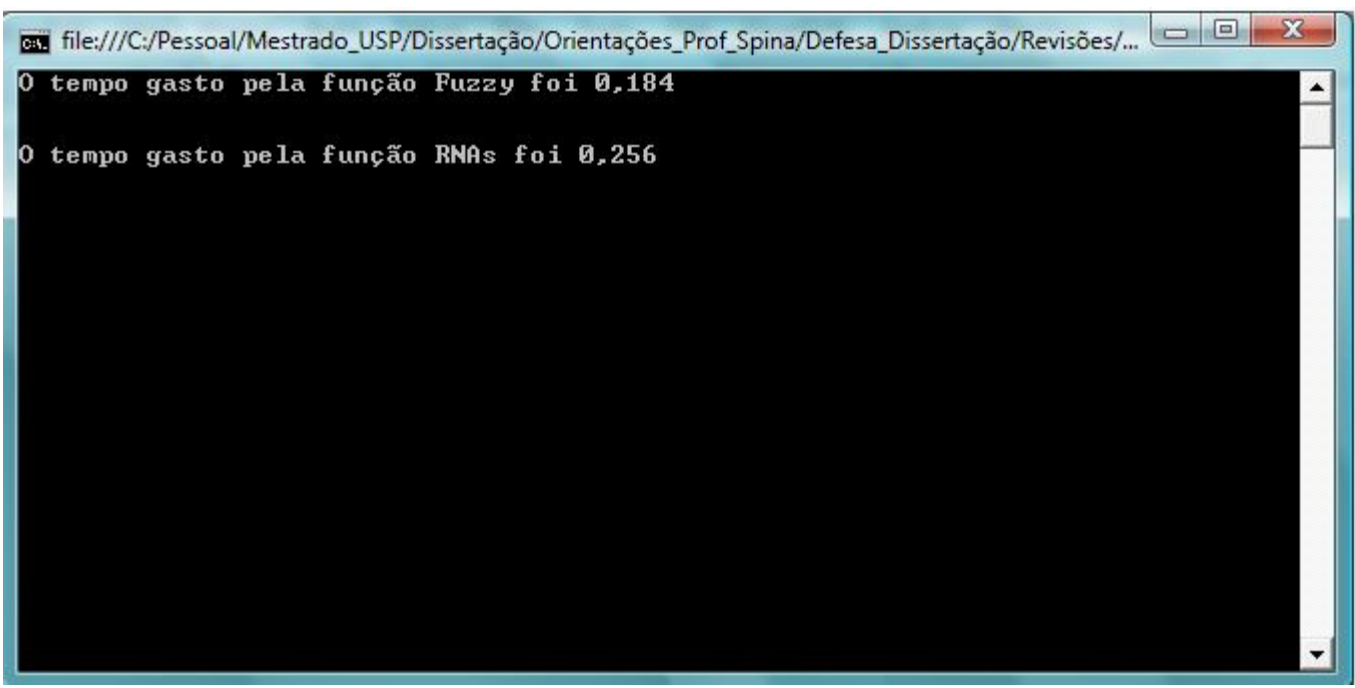

Figura 19 - Execução das funções fuzzy e RNAs. 
Os valores retornados pelos dois algoritmos, fuzzy e RNA, mostrados na Figura 19 estão expressos em milissegundos e referem-se à diferença entre tempo de início da execução de cada função e o tempo de término das mesmas.

\subsection{Análise dos Resultados}

Os dados oriundos das simulações feitas estão listados na Tabela 13.

Tabela 13 - Resultados obtidos.

\begin{tabular}{llr}
\hline \multicolumn{3}{c}{ Dados Analizados } \\
\hline \multicolumn{1}{c}{ Grandezas } & Método & Valor \\
\hline Linhas de Código & Fuzzy & 325 \\
\cline { 2 - 3 } & RNAs & 493 \\
\hline Complexidade Ciclomática & Fuzzy & 155 \\
\cline { 2 - 3 } & RNAs & 192 \\
\hline Tempo de Execução & Fuzzy & 0,184 \\
\cline { 2 - 3 } & RNAs & 0,256 \\
\hline
\end{tabular}

Fonte: Autor

Os dados listados na Tabela 13 explicitam as diferenças de valores entre os dois métodos, fuzzy e RNAs, no que diz respeito principalmente ao tempo que ambos os algoritmos gastam para executarem uma configuração básica de para os dois métodos. Estas diferenças por menores que sejam suas variações notou-se que fuzzy possui valores inferiores aos de RNAs quer sejam pelo número de LCs, ou pela $\mathrm{CC}$ ou mesmo pelo TE. Ressalta-se, porém, que à medida que aumentam os valores de ambos os modelos quer sejam regras de inferências ou neurônios, a diferença mantém-se, fuzzy menor que RNAs.

Como forma de melhor evidenciar as diferenças numéricas entre os dois modelos gerou-se três gráficos comparativos entre estes valores considerando cada uma das métricas observadas. 


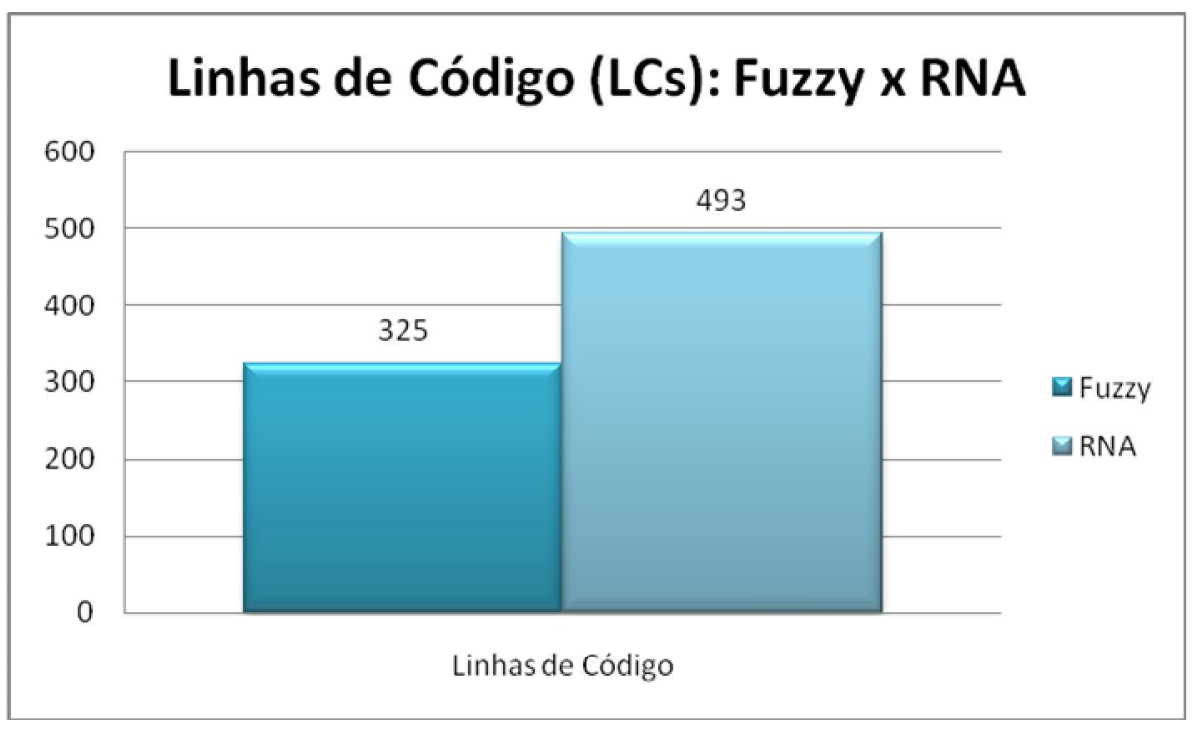

Gráfico 1 - Gráfico comparativo entre LCs Fuzzy x RNAs.

No Gráfico 1, analisou-se as LCs entre fuzzy e RNAs.

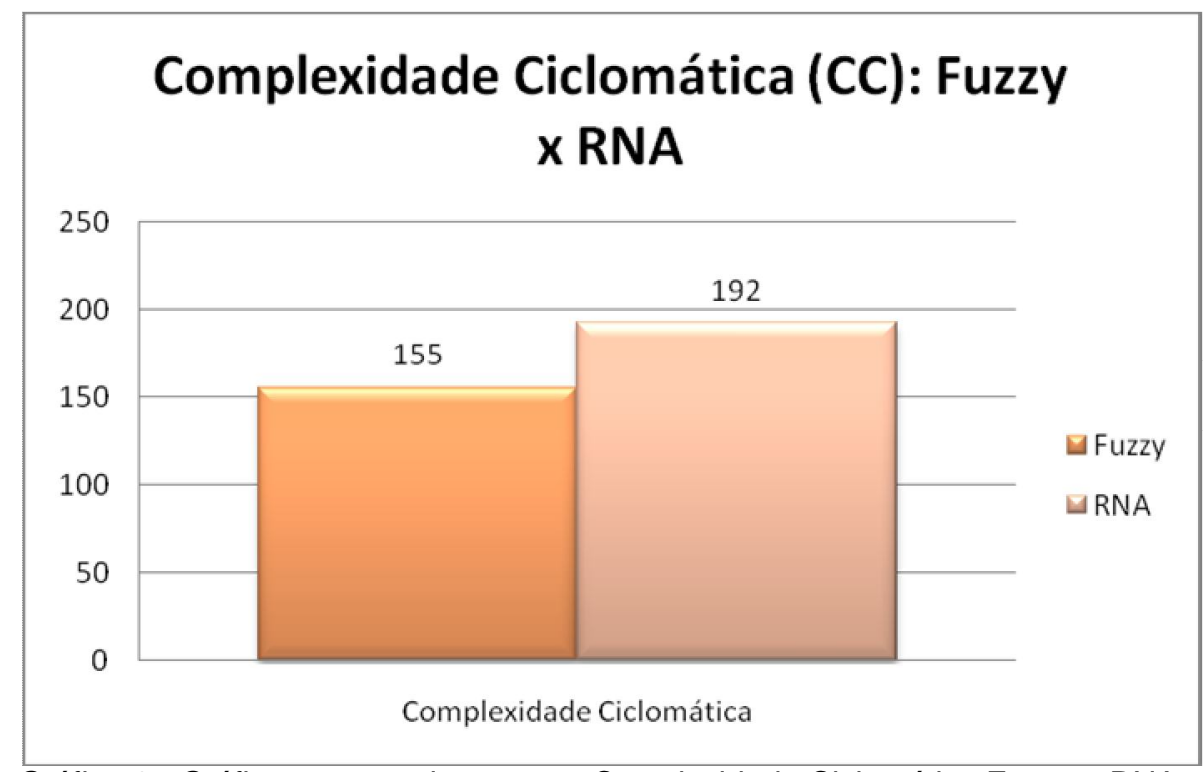

Gráfico 2 - Gráfico comparativo entre a Complexidade Ciclomática Fuzzy e RNAs. 


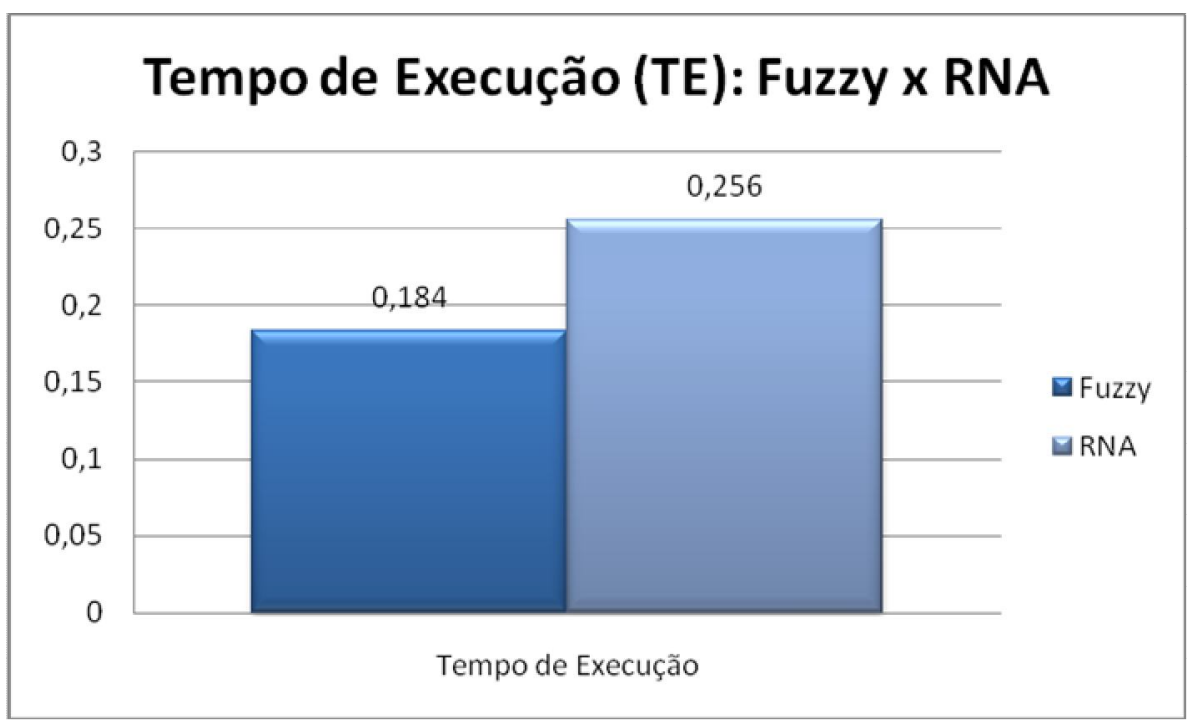

Gráfico 3 - Gráfico Comparativo do Tempo de Execução entre Fuzzy e RNAs.

Os gráficos 2 e 3, analisou-se as CC e TE entre fuzzy e RNAs, respectivamente.

\subsection{Considerações Parciais}

Este capítulo demonstrou, por meio de trabalhos relacionados e de uma simulação objetivando a comparação entre os dois métodos RNAs e fuzzy. Os resultados obtidos com as simulações apontam de fato para o método fuzzy tendo em vista o mesmo ter apresentado menores percentuais nas métricas de CC e LC como também no TE. 


\section{CONSIDERAÇÕES FINAIS}

No capitulo cinco formulou-se uma experimentação confrontando dois métodos de inteligência computacional, fuzzy e RNAs. Na qual o principal objetivo desta comparação resume-se na aplicação de um ou outro destes métodos como classificador de casos de testes gerados na ferramenta proposta ATSI.

\subsection{Avaliação do trabalho realizado}

O estudo comparativo entre fuzzy e RNAs realizado por Cios, Sala e Berke (1996) comprovam a eficácia de ambos os métodos. Ressaltam, porém, a flexibilidade e fácil adaptabilidade de fuzzy frente às mudanças que podem ser efetuadas pelo especialista.

Comprovar matematicamente sua eficácia pode não ser um fator determinante para a definição e/ou adoção de um ou outro método. Considerou-se o fator tempo para evidenciar qual dos dois algoritmos pode gerar maior consumo dos recursos computacionais com isto inseriu-se marcos de tempo nos algoritmos referentes aos dois métodos com o objetivo de gerar dados quantitativos para análise do tempo de execução de ambos os métodos.

O resultado obtido com este primeiro parâmetro de avaliação mostra a execução do método fuzzy apresentando um tempo menor que a execução da RNA, sendo portanto comprovado que o algoritmo fuzzy é mais rápido que a RNA, considerando o framework AForge. Ressalta-se, porém, que pelo fato do algoritmo fuzzy ter apresentado o tempo de execução menor que o tempo da RNA não implica que fuzzy seja melhor aplicado na ferramenta proposta.

As métricas de quantidade de Linhas de Código (LC) e Complexidade Ciclomática (CC) também foram utilizadas nas simulações. Assim como os objetivos dos marcos de tempo é a produção de valores quantitativos para à análise comparativa entre os métodos estudados a LC e a CC também tiveram o mesmo objetivo. Ressalta-se o uso da ferramenta "Code Metrics" do MS-Visual Studio para a extração dos valores para estas duas métricas.

Os valores mostrados na Gráfico 1 e Gráfico 2 ressaltam que para a métrica CC o método fuzzy tem menos caminhos a percorrer no algoritmo que RNA o que 
pode comprovar a sua eficiência sobre o outro método analisado e com menor número de linhas de código.

Uma RNA tem como principal objetivo gerar aprendizado a partir de uma base de treinamento e de um tutor (professor). Entretanto, o objetivo da simulação foi tão somente a comparação algorítmica entre as RNAs e fuzzy a fim de definir um método para classificar os casos de testes.

Os resultados obtidos com a comparação apontam como um método fuzzy que possivelmente possa ser utilizado na ferramenta proposta ATSI, para classificar os casos de testes gerados devido a sua eficiência e o poder de transformar elementos conhecidos em elementos subjetivos e por fim pontuando-os.

\subsection{Contribuições e limitações}

Durante o desenvolvimento do trabalho desenvolveu-se uma ferramenta como prova de conceito, utilizando os conceitos pesquisados e atendendo algumas técnicas de teste de software estudadas neste trabalho.

Disponibilizaram-se o diagrama de Casos de Uso da Linguagem Unificada de Modelagem (Unified Modeling Language - UML) como também as API's utilizadas no teste do ATSI e seus respectivos códigos fontes.

Os resultados que a geração de casos de testes com maior índice de cobertura e que a ferramenta ATSI possa de fato contribuir para melhoria do processo de preparação e execução de testes de software funcionais.

O método empregado para a geração dos casos de testes, Aprendizado de Conjunto de Regras (ACR), é um algoritmo que utiliza entidades de um banco de dados para considerar os seus exemplos e assim gerar novos exemplos o que se pode entendê-lo como simples sob o ponto de vista tecnológico, entretanto complexo sob o ponto de vista da inteligência computacional.

Considerando o fato de que os algoritmos de aprendizado de conjunto de regras não sejam tão utilizados e considerando também, o estudo e a experimentação realizada neste trabalho sobre as RNAs sugerem-se a utilização das RNAs como gerador de casos de testes no lugar de algoritmos de aprendizado de regras tendo em vista a comprovação da eficácia das RNAs.

Os métodos fuzzy e aprendizado de conjunto de regras foram aplicados em uma ferramenta, prova de conceitos, contendo as funcionalidades mínimas do ATSI, 
tais quais: montar a base de exemplos (mapa de requisitos); aplicar uma técnica de testes de caixa preta, particionamento por classe de equivalência; gerar os testes obedecendo os critérios da técnica de testes adotada e utilizando o algoritmo de cobertura seqüencial; por fim o classificador de testes contendo uma máquina de inferência fuzzy. Ao executar esta ferramenta, observou-se que uma dada classe de valores fora dos limites mínimo e máximo, estabelecidos pela configuração dos testes, na ferramenta, foram recusados pelo classificador dos testes (fuzzy) tendo em vista que o conjunto fuzzy definido para este experimento estava dentro da faixa de valores válidos, entre os valores mínimo e máximo. Com isto observado, concluíse que há uma limitação quanto a valores a serem analisados por uma máquina de inferência fuzzy.

\subsection{Sugestões e Trabalhos futuros}

É importante um estudo comparativo entre os métodos RNA e algoritmos de aprendizado de conjunto de regras para melhor validar a hipótese de que as RNAs são de fato, mais eficazes que os ACRs.

Sugere-se a aplicação de mais técnicas de casos de testes funcionais utilizando as RNAs a fim de observar o comportamento e desempenho perante situações diversificadas de testes funcionais.

Sugere-se também avaliar as faixas de valores das variáveis a serem submetidas ao classificador de testes. Esta avaliação é importante face à limitação apresentada pela máquina fuzzy do classificador de casos de testes, observado no uso da ferramenta na prova de conceitos pois, quando o conjunto de valores crisp já está definido e a máquina de inferência recebe um valor fora do intervalo, o conjunto fuzzy apresenta falha.

Faz-se importante a implementação da ferramenta ATSI a fim de aplicar outras técnicas de testes como também outras técnicas de inteligência computacional. 


\section{REFERÊNCIAS}

ABRAN, A. Guide to the software engineering body of knowledge. Los Alamitos: IEEE Computer Society, p. 5-1, 2004.

AFORGENET. /Open Source Framework in C\# designed for developers and researchers in the fields of Computer Vision and Artificial Intelligence - image processing, neural networks, genetic algorithms, fuzzy logic, machine learning, robotics./ 2008, Reino Unido. [online] Disponível em: http://www.aforgenet.com/framework/. Acessado em: 28 maio 2010.

ASSOCIAÇÃO BRASILEIRA DE NORMAS TÉCNICAS. ISO/IEC 9126-1. Qualidade de produto: modelo de qualidade. p. 7-12, 2003.

AGARWAL, D. A comparative study of artificial neural network and info fuzzy network on their use in software testing. 2004. Tese (Doutorado). Universidade do Sul da Flórida, 2004.

ANSARI, A. Q. et al. Integrating Fuzzy Logic and Data Mining: Impact on Cyber Security. In: International Conference on fuzzy systems and knowledge discovery. 4, Haikou, 2007. Anais FSKD, p. 498-502, 2007.

BARRETO, J. M. Introdução às redes neurais artificiais. In: Escola Regional de Informática da SBC Regional Sul, 5, 2002. Maringá, p. 41-71, 2002.

BERNARDO, P. C.; KON, F. A importância dos testes automatizados. Engenharia de Software Magazine, v.1, n. 3, p. 54-57, 2008.

BIANCHI, R. E. Extração de conhecimento simbólico em técnicas de aprendizado de máquina caixa-preta por similaridade de rankings. 2008. Tese (Doutorado). Instituto de Ciências Matemáticas e de Computação da Universidade de São Paulo, São Carlos, 2008.

BRAGA, A. P. et al. Sistemas inteligentes: Redes neurais artificias. . Barueri: Manole; 2005.

BURNSTEIN, I. Pratical software testing, A process-oriented approach. New York. Springer Professional Computing, 2003.

CARVALHO, A. P. L. F. de. Redes neurais artificiais. 2009, Brasil. [online] Disponível em: http://www.icmc.usp.br/ andre/research/neural/index.htm. Acessado em: 17 maio 2010.

CHARETTE, R. N. Learning from software failure. 2007, <Local>. [online] Disponível em: http://www.spectrum.ieee.org/computing/software/learning-fromsoftware-failure. Acessado em: 17 de abril de 2010. 
CIOS, K. J.; SALA, D. M.; BERKE, L. A comparison of neural networks and fuzzy logic methods for process modeling. NASA Technical Memorandum 107236. Ohio, 1996.

COIMBRA, W. A. P. et al. Análise e simulação de requisitos não-funcionais aplicada a um sistema para controle de tráfego aéreo. In: Congresso internacional de gestão da tecnologia e sistemas de informação, São Paulo, CONTECSI Anais e Resumos. São Paulo. p. 1943-1959, 2007.

CRESPO, N. A. et al. Uma metodologia para teste de software no contexto da melhoria de processo. In: Simpósio Brasileiro de Qualidade de Software, 3, Brasilia: Anais SBQS, 2004.

DELAMARO, M.; MALDONADO, J. C.; JINO, M. Introdução ao teste de software. São Paulo. São Paulo: Elsevier, 2007.

DINIZ, A. A. Processo de inspeção de artefatos de testes funcionais de software. 2008. Dissertação (Mestrado). Instituto de Pesquisas Tecnológicas do Estado de São Paulo, São Paulo, 2008.

GAO, J. Z.; TSAO, H.S.J; WU, Y.. Testing and quality assurance for componentbased software. Norwood, Artech House, 2003.

HAMBLING, B. et al. Software testing. United Kingdown. The British Computer Society, 2007.

HARMAN, M. Automated test data generation using search based software engineering. In: International Workshop on Automation of Software Test. 2, Minneapolis, 2007. Londres, p. 2-2, 2007.

INSTITUTE OF ELETRICAL AND ELETRONICS ENGINEERS. IEEE 610.12: Standard glossary of software engineering terminology. New York. 1990.

JAVED, A. Z.; STROOPER, P. A.; WATSON, G. N. Automated generation of test cases using model-driven architecture. In: Workshop on Automation of Software Test. 2, Minneapolis, 2007. Anais AST. Minneapolis, p. 3, 2007.

$\mathrm{JIN}, \mathrm{H}$. et al. Artificial neural network for automatic test oracles generation. In: International conference on computer science and software engineering. 4, Wuhan, Proceedings International Conference on Computer Science and Software Engineering, 2008. China, p. 727-730, 2008.

KAEHLER, S. D. Fuzzy logic an introduction. 1998. [online] Disponível em: http://www.seattlerobotics.org/encoder/mar98/fuz/fl_part4.html \#MEMBERSHIP FUNCTIONS. Acessado em: 17 de maio de 2010.

KLIR, G. J.; YUAN, B.; Fuzzy Sets and Fuzzy Logic: Theory and Applications. New Jersey. Prentice-Hall, 1995. 
LAST, M.; FRIEDMAN, M.; KANDEL, A. The data mining approach to automated software testing. International conference on knowledge discovery and data mining. 9, Anais SIGKDD, 2003. Washington, 2003. Washington, p. 388-396, 2003.

LEATHER, H.; BONILLA, E.; O'BOYLE, M. Automatic Feature Generation for Machine Learning Based Optimizing Compilation. In: International Symposium on Code Generation and Optimization. 21, Seattle, 2009. Anais CGO. Seattle, p. 81-91, 2009.

MAYERS, G. J. The art of software testing. New Hersey: John Wiley e Sons. 2004.

MICHAEL, C. C.; MCGRAW, G.; SCHATZ, M. A. Generating Software Test Data by Evolution. IEEE Transactions on software engineering, $v 27, n$. 12, December. $p$. 1085, 2001.

MITCHEL, T. M. Machine Learnning. Pittsburgh. McGraw Hill, 1997.

MONARD, M. C.; BARANAUSKAS, J. A. Sistemas Inteligentes Fundamentos e Aplicações. Barueri. Monole. 2005.

NETO, L. F. Minimização de Conjuntos de Casos de Teste para Máquinas de Estados Finitos. 2008. Dissertação (Mestrado). Instituto de Ciências Matemáticas e de Computação da Universidade de São Paulo, São Carlos, 2008.

NETO, P. D. MODEST: Um método de teste baseado em modelos. 2006.Tese (Doutorado). Instituto de Ciências Exatas da universidade Federal de Minas Gerais, Belo Horizonte, 2006.

PAPO, J. Benefícios econômicos da automação de testes unitários - Sua suite de testes é tão valiosa quanto seu código. 2009, São Paulo. [Online] Disponível em: $\quad$ http://josepaulopapo.blogspot.com/2009/10/testes-unitarios-beneficioseconomicos.html. Acessado em: 28 de Outubro de 2009.

PRATI, R. C. Novas abordagens em aprendizado de máquina para a geração de regras, classes, desbalanceamentos e ordenação de casos. 2006. Tese (Doutorado). Instituto de Ciências Matemáticas e de Computação da Universidade de São Paulo, São Carlos, 2006.

PRESSMAN, R. S. Engenharia de Software, New York. Pearson; 2005.

RAHMAN, A.M.J. M. Z.; BALASUBRAMANIE, P. An efficient algorithm for mining maximal frequent item sets; Journal of Computer Science. v. 4, n. 8: p. 638-645; Science Publications, 2008.

REZENDE, S. O.; PRATI, R. Sistemas Inteligentes - Fundamentos e Aplicações. Barueri: Manole; 2005.

RECH, J.; ALTHOFF, K. Artificial intelligence and software engineering: status and future trends. Finland. Idea Group: KI, v.18, n.3, p. 5-11, 2004. 
ROCHA, A. D. et al. Teste Funcional: uma abordagem auxiliada por aspectos. In: Workshop Brasileiro de Desenvolvimento de Software Orientado a Aspectos. 1, 2004, Brasília. Anais do Workshop Brasileiro de Desenvolvimento de Software Orientado a Aspectos, 2004. v. 1. p. 1-8, 2004.

SANTOS, P. Sobre o método comparativo: notas iniciais. 2007. [online] Disponível em: http://pt.shvoong.com/social-sciences/1717426-sobre-método-comparativonotas-iniciais/. Acessado em: 03 de Dezembro de 2009.

SHAW, I. S.; SIMÕES, M. G. Controle e modelagem fuzzy. São Paulo. São Paulo: Ed. Edgard Blücher, 1999.

SIMÕES, A. S.; COSTA, A. H. R. C; ANDRADE, M. T. C. de. Utilizando um Classificador Fuzzy para a Seleção Visual de Laranjas. In: Workshop de Computação. xx, São José dos Campos, 2001. Anais WORKCOMP 2001. São José dos Campos, 2001. p. 113-117, 2001.

TALON, B. et al. Learning software testing using a collaborative activities oriented platform. In: IEEE International Conference on Advanced Learning Technologies. 9, França, 2009. Anais ICALT. França: p. 443-445, 2009.

WRITTEN, I. H.; FRANK, E. Data mining: practical machine learning tools and techniques. San Francisco. San Francisco: Elsevier Inc, 2005.

XUE, M.; ZHU, C. A study and application on machine learning of artificial intelligence. In: International Joint Conference on Artificial Intelligence. 55, Washington, 2009. Anais JCAl. Washington, p. 272-274, 2009.

YING, $\mathrm{H}$. et al. Comparison of necessary conditions for typical Takagi-Sugeno and Mamdani fuzzy systems as universal approximators. In: IEEE Transactions on systems, man, and cybernetics - Part A: systems and humans. 1999. IEEE Transactions on systems, man, and cybernetics. v. 29, n. 5, p. 508-514, 1999.

ZADEH, L. A. Outline of a New Approach to the analysis of complex systems and Decision Process. In: IEEE Transactional on systems, man, and cybernetics.1973. IEEE Transactions on systems, man, and cybernetics. v. SMC-3, n. 1, p. 28-44, 1973. 